\title{
Bycatch and discard survival rate in a small-scale bivalve dredge fishery along the Algarve coast (southern Portugal)
}

\author{
Mariana Anjos 1,*, Fábio Pereira 1,2,*, Paulo Vasconcelos ${ }^{2,3}$, Sandra Joaquim ${ }^{2,4}$, \\ Domitília Matias ${ }^{2,4}$, Karim Erzini ${ }^{1}$, Miguel Gaspar ${ }^{1,2}$ \\ ${ }^{1}$ Centro de Ciências do Mar (CCMAR), Universidade do Algarve, Campus de Gambelas, 8005-139 Faro, Portugal. \\ (MA) E-mail: mariananjos@ hotmail.com. ORCID iD: http://orcid.org/0000-0001-5518-2110 \\ (FP) E-mail: fpereira@ipma.pt. ORCID iD: http://orcid.org/0000-0002-1806-0189 \\ (KE) E-mail: kerzini@ualg.pt. ORCID iD: http://orcid.org/0000-0002-1411-0126 \\ (MG) (Corresponding author) E-mail: mbgaspar@ipma.pt. ORCID iD: http://orcid.org/0000-0001-9245-8518 \\ ${ }^{2}$ Instituto Português do Mar e da Atmosfera (IPMA), Avenida 5 de Outubro s/n, 8700-305 Olhão, Portugal. \\ (PV) E-mail: paulo.vasconcelos@ipma.pt. ORCID iD: http://orcid.org/0000-0002-2119-2297 \\ (SJ) E-mail: sandra@ipma.pt. ORCID iD: http://orcid.org/0000-0002-6324-5908 \\ (DM) E-mail: dmatias@ipma.pt. ORCID iD: http://orcid.org/0000-0002-2191-7497 \\ ${ }^{3}$ Centro de Estudos do Ambiente e do Mar (CESAM), Departamento de Biologia, Universidade de Aveiro, \\ Campus de Santiago, 3810-193 Aveiro, Portugal. \\ ${ }^{4}$ Centro Interdisciplinar de Investigação Marinha e Ambiental (CIIMAR), Universidade do Porto, Avenida General Norton \\ de Matos s/n, 4450-208 Matosinhos, Portugal. \\ * These authors contributed equally to the work and should be considered co-first authors of the study
}

\begin{abstract}
Summary: Although the bivalve dredge used on the Algarve coast (southern Portugal) is highly selective for the target species, in some periods of the year the bycatch can exceed the catch of the commercial species. The present study aimed to quantify the bycatch and discards, estimate damage and mortality, and propose management measures to minimize discards and mortality. A total of 15 fishing surveys (60 tows) were performed using two types of dredges ("DDredge" targeting Donax trunculus and "SDredge" targeting Spisula solida and Chamelea gallina). Of the 85257 individuals (392.4 kg) of 52 taxa that were caught, $73.4 \%$ belonged to the target species, $22.1 \%$ to commercially undersized target species and $4.5 \%$ to bycatch species. Bycatch rates were lower for SDredge (13.5\% in number and $6.3 \%$ in weight) than for DDredge $(46.0 \%$ in number and $32.9 \%$ in weight). Damage and mortality rates were also lower using SDredge $(1.3 \%$ and $1.0 \%$ of the total catches, respectively) than using DDredge (4.0\% and $2.8 \%$ of the total catches). Survival experiments revealed the diverse vulnerability of the taxa and confirmed the influence of the damage score on the mortality rate. The results gathered in the present study encourage the adoption of a bycatch reduction device to reduce both direct and indirect mortality.
\end{abstract}

Keywords: bivalve dredging; bycatch; discards; damage score; survival rate; metallic grid dredge; fishing gear technical design; bycatch reduction device

Tasa de supervivencia de capturas incidentales y descartes en una pesquería a pequeña escala de bivalvos con rastro remolcado en la costa del Algarve (sur de Portugal)

Resumen: Aunque la draga de bivalvos utilizada en la costa del Algarve (sur de Portugal) es altamente selectiva para las especies objetivo, en algunos períodos del año la captura incidental puede exceder la captura de las especies comerciales. En este contexto, el presente estudio tuvo como objetivo cuantificar las capturas incidentales y los descartes, estimar el daño y la mortalidad, y proponer medidas de gestión para minimizar los descartes y la mortalidad. Se realizaron un total de 15 embarques (60 arrastres) utilizando dos tipos de dragas ("DDredge" dirigida a Donax trunculus y "SDredge" dirigida a Spisula solida y Chamelea gallina). En total, se capturaron 85257 individuos $(392.4 \mathrm{~kg})$ pertenecientes a 52 taxones, distribuidos entre especies objetivo (73.4\%), especies objetivo por debajo de la talla legal (22.1\%) y especies de captura incidental (4.5\%). Las tasas de captura incidental fueron menores en SDredge (13.5\% número y 6.3\% peso) que en DDredge (46.0\% número y $32.9 \%$ peso). Las tasas de daños y mortalidad también fueron menores usando SDredge (1.3\% y $1.0 \%$ de las capturas totales) que usando DDredge ( $4.0 \%$ y $2.8 \%$ de las capturas totales). Los experimentos de supervivencia revelaron la diferente vulnerabilidad de los taxones y confirmaron la influencia del nivel de lesiones en la tasa de mortalidad. Los resultados del presente estudio fomentan la adopción de un dispositivo de reducción de capturas incidentales (BRD) para reducir la mortalidad directa e indirecta.

Palabras clave: draga de bivalvos; capturas incidentales; descartes; nivel de lesión; tasa de supervivencia; draga de rejilla metálica; diseño técnico de artes de pesca; dispositivo de reducción de capturas incidentales. 
Citation/Como citar este artículo: Anjos M., Pereira F., Vasconcelos P., Joaquim S., Matias D., Erzini K., Gaspar M. 2018. Bycatch and discard survival rate in a small-scale bivalve dredge fishery along the Algarve coast (southern Portugal). Sci. Mar. 82S1: 75-90. https://doi.org/10.3989/scimar.04742.08A

Editor: M. Demestre.

Received: December 5, 2017. Accepted: May 17, 2018. Published: June 14, 2018.

Copyright: (C) 2018 CSIC. This is an open-access article distributed under the terms of the Creative Commons Attribution 4.0 International (CC BY 4.0) License.

\section{INTRODUCTION}

Small-scale fisheries (SSFs) are strongly represented in all European Union (EU) member states (Guyader et al. 2013), so many coastal communities rely on fisheries and fishing-related activities as a means of subsistence, income and employment (Oliveira 2014) that has created an ancient cultural heritage and socio-economic dependence. In Portugal, the bivalve dredging fleet is of great importance among the SSFs, accounting for a large number of vessels and many fishermen, a high volume of catches and high value of the products (Oliveira 2014). The vast majority of the Portuguese fishing fleet is composed of artisanal vessels (Oliveira et al. 2007), and the largest bivalve dredging fleet is based on the Algarve coast (southern Portugal), with 53 vessels operating an average of 177 days year ${ }^{-1}$ (DGRM 2015).

In Portugal, bivalve dredge fisheries have been performed since 1969 (Chícharo et al. 2002a). On the Algarve coast, the dredging fleet targets mainly three commercially valuable bivalve species: Spisula solida, Chamelea gallina and Donax trunculus (Gaspar et al. 2015). The surf clam (S. solida) occurs mainly between 3 and $14 \mathrm{~m}$ depth; it is the most abundant bivalve species in this area and has shown increasing densities over the last decade. The striped venus (C. gallina) has a similar depth distribution, being found mainly from 3 to $10 \mathrm{~m}$ depth (Gaspar et al. 2015). The donax clam (D. trunculus) occurs within a narrower bathymetric range (0-5 m depth, with higher densities at $3 \mathrm{~m}$ depth) (Gaspar et al. 2015), but it is among the most important molluscan species commercially exploited in the southern Iberian Peninsula and western Mediterranean Sea (Gaspar et al. 1999, Tirado et al. 2011).

The mode of operation and technical design of mechanized dredges have undergone gradual developments thanks to studies aimed at improving dredge selectivity (Gaspar 1996, Gaspar et al. 1999, 2002a) and reducing catch mortality (Gaspar and Monteiro 1999, Gaspar et al. 2003a, Leitão et al. 2009). The most recent modification to the dredge design included the adoption of a metallic grid box to retain the catches above the target species minimum landing size (MLS), by filtering out smaller individuals of both target and non-target species. Though it is more efficient and selective than previous dredge designs (Gaspar et al. 2001, 2003a, Leitão et al. 2009), in some periods of the year the amount of bycatch collected by this gear can exceed the catch of the target species, especially in late spring and early summer (Gaspar and Chícharo 2007).
The bycatch (capture of non-target organisms) includes incidental catches, non-target catches retained by fishermen, and discards, i.e. catches returned to the sea (McCaughran 1992, Alverson et al. 1996) because they are unmarketable species, highly damaged specimens or individuals below the MLS (Kelleher 2005). By changing the species relative abundance, together with the population structure of prey and/or predators, bycatch may lead to structural and functional disturbances in the ecosystem (Pauly et al. 2002, Thrush and Dayton 2002). For instance, bycatch can modify the diversity, biomass and productivity of the associated biota (Jennings and Kaiser 1998); disrupt trophic interactions (e.g. removal of prey and/or predators) (Crowder and Murawski 1998, Pauly et al. 1998) with subsequent modifications to food webs (Gaspar et al. 2001); change the structure of benthic communities in the short and long term (Jenkins et al. 2001); alter species foraging behaviour (FAO 2003); reduce the ratio of large- to small-bodied species (Bianchi et al. 2000); and affect fishing yield in other fisheries (Clark and Hare 1998)

Discarding by bivalve dredging vessels would not constitute a major problem if the discarded individuals survive after returning to the sea (Gaspar and Chícharo 2007). However, it is crucial to analyse the composition of discards in order to propose new strategies to minimize their impact (Urra et al. 2017). Indeed, fisheries management policies recommend a reduction in the discards (Catchpole et al. 2005) and the adoption of market-based approaches to promote added value for bycatch species (Leitão and Baptista 2017). The reformed Common Fisheries Policy of the EU (EC 2014) imposes a discard ban for all species subject either to quotas or MLS, resulting in a mandatory landing obligation for all catches (Vogel et al. 2017). However, in certain circumstances, this regulation allows some discarding when scientific evidence demonstrates high probabilities of survival of the discards (Morfin et al. 2017).

In order to further assess fishing impacts, the survival of bycatch is often estimated through damage scales and survival experiments (ICES 2014). Because damaged individuals are more vulnerable to predation and disease, it is crucial to accurately evaluate their level of damage upon discard (Pranovi et al. 2001). Many studies on this topic have focused on bycatch and mortality resulting from fish and shrimp trawling (for a review, see Broadhurst et al. 2007), but few have dealt with discard mortality in bivalve dredge fisheries (e.g. Hauton et al. 2003, Leitão et al. 2009, Urra et al. 2017). 
In the bivalve dredging fishery, the optimal situation would be one in which maximum efficiency, low bycatch of non-target species, retention of very few undersized individuals and a low proportion of damaged individuals prevailed as prerequisites to mitigate the effects of the discard ban or similar policies. In order to achieve these goals, management measures should be implemented and fishing gear modified according to the local environmental conditions, the population status of the target species and current discard rates. The present study aimed to 1) characterize and quantify the bycatch of the metallic grid dredge used in the fishery targeting $S$. solida, C. gallina and D. trunculus along the Algarve coast; 2) evaluate seasonal variations; 3 ) estimate damage and mortality by using damage scales and performing survival experiments; and 4) propose management measures to minimize both discards and mortality.

\section{MATERIALS AND METHODS}

\section{Fishing surveys and biological sampling}

Fishing surveys were performed on board two commercial bivalve dredging vessels, Cláudia Marina (F1106-L) and Renovadora (O-1949-C), operating in the same areas near Olhão on the Algarve coast (Fig. 1). Sampling was made bimonthly from February to July, except during the mandatory seasonal closure in the fishery (1 May to 15 June) to protect the spawning and larval settlement of the target bivalve species.

Considering the dissimilar depth distribution of the target species, two bathymetric intervals were sampled, 5-10 m depth for the sympatric S. solida and $C$. gallina using the "Spisula dredge" (SDredge) and 2-4 m depth for D. trunculus using the "Donax dredge" (DDredge). The main technical specifications of SDredge and DDredge are identical, except for the spacing between bars of the metallic grid box (SDredge $=12 \mathrm{~mm}$ and DDredge $=8 \mathrm{~mm}$ ). In each fishing survey, 5-minute tows were performed using two identical dredges operated simultaneously and side by side (leeward and windward dredges) at a towing speed of 2 to 4 knots.

All catches from each tow and dredge were analysed separately in the laboratory in order to characterize the catch composition and assess the discard rate.

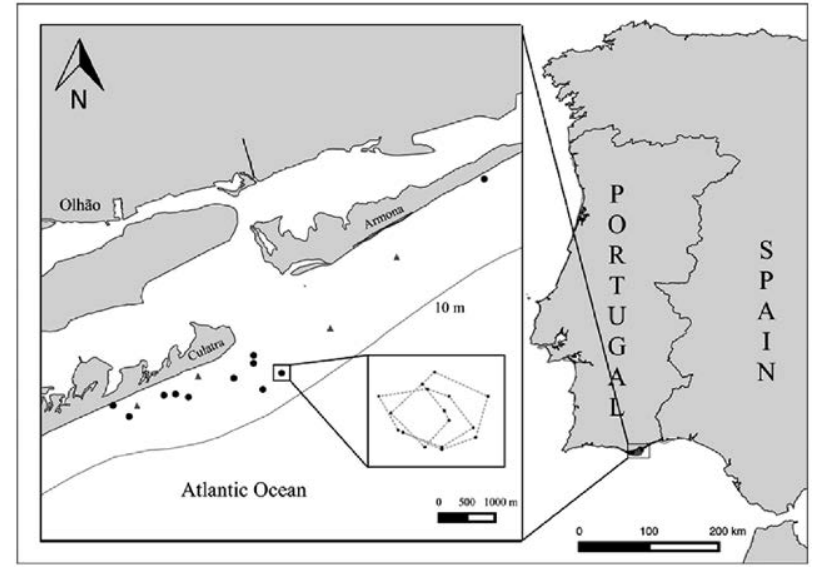

Fig. 1. - Map showing the location of the bivalve fishing surveys performed using SDredge (triangles) and DDredge (circles) along the Algarve coast (southern Portugal).

For this purpose, all specimens caught were identified to the lowest possible taxonomic level, counted, measured using a digital calliper and weighed on a top-loading digital balance. Individuals of the three target bivalve species below the legally established MLS (25 mm shell length) and non-target species were considered bycatch.

In order to avoid unnecessary disturbance during handling and sampling procedures, additional fishing surveys (three fishing days in April, October and November 2016) were performed with the specific purpose of survival experiments. Individuals were also identified, counted and separated by taxonomic groups (whenever necessary). Onboard procedures were representative of normal fishing practices and the organisms were handled quickly and carefully in order to minimize any injuries.

The damage rate and the mortality rate of the discards were estimated using a damage scale (Table 1) applied to all individuals caught during dredging. According to this methodology proposed by Gaspar et al. (2001), the damage rate corresponds to the proportion of damaged individuals (i.e. assigned with damage scores $\mathrm{D}_{1}$ to $\mathrm{D}_{3}$ ), whereas the mortality rate corresponds to the proportion of individuals with high likelihood of death (damage score $\mathrm{D}_{2}$ ) and dead specimens (damage score $\mathrm{D}_{3}$ ).

Table 1. - Damage scale and criteria adopted for scoring different taxa caught as target species or bycatch during bivalve dredging (adapted from Gaspar et al. 2001).

\begin{tabular}{|c|c|c|c|c|}
\hline \multirow[b]{2}{*}{ Taxa } & \multicolumn{4}{|c|}{ Damage scores } \\
\hline & $\mathrm{D}_{0}$ & $\mathrm{D}_{1}$ & $\mathrm{D}_{2}$ & $\mathrm{D}_{3}$ \\
\hline Polychaeta & In good condition & & & Sectioned \\
\hline Gastropoda & In good condition & Edge of shell chipped & Shell cracked or punctured & Crushed /dead \\
\hline Bivalvia & In good condition & Edge of shell chipped & Hinge broken & Crushed /dead \\
\hline Anomura & In good condition & Out of shell and intact & Out of shell and damaged & Crushed /dead \\
\hline Brachyura & In good condition & Legs missing / small carapace cracks & Major carapace cracks & Crushed /dead \\
\hline Other Decapoda & In good condition & & & Dead \\
\hline Asteroidea & In good condition & Arms missing & Worn and arms missing & Dead \\
\hline Ophiuroidea & In good condition & Arms missing & $\begin{array}{l}\text { Worn and arms missing / minor } \\
\text { disc damage }\end{array}$ & $\begin{array}{l}\text { Major disc damage/ } \\
\text { dead }\end{array}$ \\
\hline Echinoidea & In good condition & $<50 \%$ spine loss & $>50 \%$ spine loss / minor cracks & Crushed/dead \\
\hline Actinopterygii & In good condition & $\begin{array}{l}\text { Few scales missing / small cuts or } \\
\text { wounds }\end{array}$ & $\begin{array}{l}\text { Several scales missing / } \\
\text { severe cuts or wounds }\end{array}$ & Dead \\
\hline
\end{tabular}



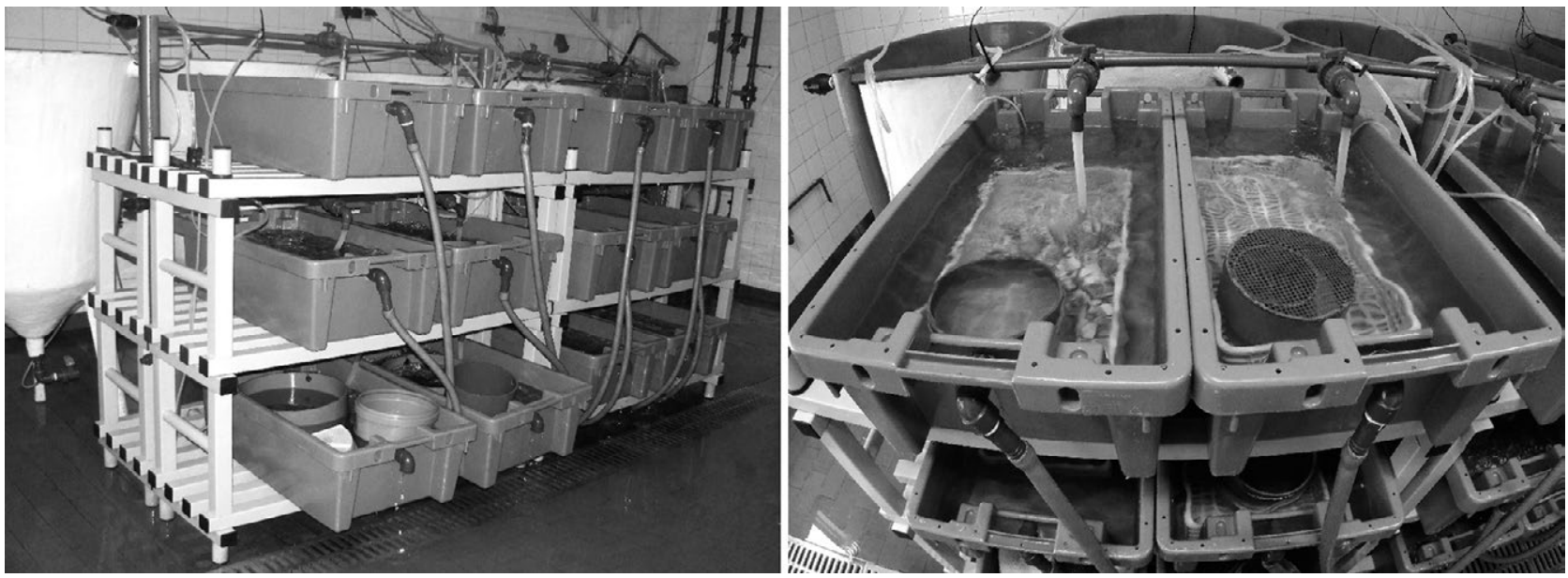

Fig. 2. - General overview of the containment facilities (flow-through system) where the survival experiments were performed in the Molluscan Aquaculture Experimental Station of IPMA.

\section{Survival experiments}

Three fishing surveys were carried out specifically to perform the survival experiments, aiming to avoid excessive handling of the catches during regular sampling. In order to estimate discard survival (excluding predation) under captive observation, both undersized individuals of the target species and bycatch species were previously subjected to a visual semi-quantitative assessment based on the damage score (Table 1). Whenever possible, this assessment was based on four quickly assessed ordinal vitality classes graduated from individuals that were intact, very lively and responsive $\left(\mathrm{D}_{0}\right)$ to individuals that were severely injured externally and moribund $\left(\mathrm{D}_{3}\right)$. Only organisms with scores $\mathrm{D}_{0}$ and $\mathrm{D}_{1}$ were used in the subsequent survival experiments, in which excessive handling procedures that might bias the survival rates were always avoided.

The survival experiments were conducted in the Molluscan Aquaculture Experimental Station of IPMA in Tavira, using a flow-through system to minimize the interference from metabolic waste products of the organisms and to maintain suitable levels of dissolved oxygen. This flow-through circuit (Fig. 2) is powered by pumping natural seawater from the adjacent Ria Formosa lagoon, which is filtered at $1 \mu \mathrm{m}$ and stored in a $200000-\mathrm{L}$ tank connected to $25-\mathrm{L}$ plastic tanks with seawater flow regulated to $48 \mathrm{~L} \mathrm{~h}^{-1}$. The survival experiments were conducted under controlled conditions in terms of seawater temperature $\left(21 \pm 1^{\circ} \mathrm{C}\right)$, salinity (35), photoperiod ( $12 \mathrm{~h}$ daylight) and $\mathrm{pH}$. Predator species were fed with bivalves, while suspension-feeding bivalves were fed ad libitum with a bispecific microalgae culture, Isochrysis aff. galbana (T-ISO) and Chaetoceros calcitrans (C. cal) in a proportion of 1:1, supplied to the water circuit through a variable-flow peristaltic pump (for further details see Barros et al. 2013).

In order to avoid degradation of the water quality, the containment facilities provided suitable accommodation space according to the number of specimens. Incompatible species were isolated, although shelter was not provided to the organisms due to logistics constraints. Captive observations to assess animal status were made at regular intervals after transfer $(5 \mathrm{~h}$; $1 \mathrm{~d} ; 2 \mathrm{~d} ; 3 \mathrm{~d} ; 4 \mathrm{~d} ; 5 \mathrm{~d}$ and $7 \mathrm{~d}$ ) during a daily-based acute monitoring period of 7 days. Following the recommendations issued in the Workshop on Methods for Estimating Discard Survival - WKMEDS (ICES 2014), a higher observation frequency was conducted during the first few hours, after which the organisms were monitored at longer intervals. Dead organisms were removed as soon as possible from the tanks to minimize water degradation and the risk of contamination. Whenever possible, additional information, such as internal damage (e.g. cut siphons in bivalves) and sexual maturation were recorded to provide further insights on the organisms' susceptibility to mortality.

\section{Data treatment and statistical analysis}

Data on both abundance and biomass caught by the two types of dredges (SDredge and DDredge) during the sampling period were analysed to assess any differences in the catch, bycatch composition, damage and mortality rates between gears.

Relationships between samples were examined through non-metric multidimensional ordination plots (MDS) based on the Bray-Curtis similarity coefficient after square root transformation (Clarke and Warwick 2001). SIMPER analysis (similarity percentage-species contribution) was performed to highlight the taxa that most contributed to the dissimilarity between the two types of dredge. Analysis of similarities (ANOSIM) (Clarke and Warwick 2001) was used to detect any great differences in bycatch and mortality composition. These analyses were performed using the software package PRIMER 6.0 (Clarke and Gorley 2006).

Analyses of variance (ANOVA) were employed to assess differences in the proportion of bycatch (abundance and biomass) and mortality rate between types of dredge, with data expressed as percentage being previously transformed to arcsine square-root values. Whenever ANOVA assumptions (normality of data and homogeneity of variances) were not achieved, the non-parametric Kruskal-Wallis test (ANOVA on 
ranks) was performed. In addition, the Spearman rank correlation was employed to assess any correlations between the weight of debris collected by the dredges and the organisms' damage rate. ANOVAs and the Spearman rank test were performed using the SigmaStat $^{\circledR}$ software package (version 12.3). In all analyses, statistical significance was set at $\mathrm{p}<0.05$.

\section{RESULTS}

\section{Catch and bycatch composition}

In the 60 tows performed during 15 fishing surveys using the two types of dredge, 85257 individuals belonging to 52 taxa distributed through six phyla were caught. Of these individuals, $73.4 \%$ belonged to target species, $22.1 \%$ to commercially undersized target species (i.e. $<$ MLS) and $4.5 \%$ to bycatch species (Table 2 ). The vast majority of the catches of the target species belonged to $S$. solida $(89.3 \%)$ followed at some distance by D. trunculus $(9.8 \%)$ and $C$. gallina $(0.9 \%)$. The overall catches weighed $392.4 \mathrm{~kg}$, of which $84.8 \%$ was accounted for by target species, $12.1 \%$ by undersized target species and $3.1 \%$ by the remaining bycatch species. Among the target species, the largest fraction of total weight corresponded to S. solida (91.8\%), which clearly prevailed over D. trunculus $(6.7 \%)$ and C. gallina (1.5\%) (Table 2). Molluscs were clearly the predominant phyla $(50.0 \%$ of all taxa, $96.1 \%$ of total abundance and $97.8 \%$ of total biomass), followed by arthropods $(21.2 \%, 3.4 \%$ and $1.5 \%$, respectively), whereas echinoderms, annelids, chordates and nemerteans were almost residual (together accounting for $28.8 \%$ of taxa but representing only $0.5 \%$ of abundance and $0.6 \%$ of biomass) (Table 2). Detailed information on the abundance and biomass of all the taxa caught using the two types of dredge (Tables 3 and 4) show that Bivalvia was the most represented class (20 species)

Table 2. - Total abundance (number of individuals) and biomass (g) of the target species, undersized target species $(<\mathrm{MLS})$ and bycatch species caught using two types of bivalve dredge (SDredge and Ddredge) in the fishing surveys performed along the Algarve coast

\begin{tabular}{lcccc}
\multicolumn{4}{c}{ (southern Portugal). } \\
& \multicolumn{3}{c}{ Abundance } & \multicolumn{2}{c}{ Biomass } \\
& Number & $(\%)$ & Weight & $(\%)$ \\
\hline TARGET SPECIES & & & & \\
Chamelea gallina & 567 & 0.9 & 4933.0 & 1.5 \\
Donax trunculus & 6111 & 9.8 & 22237.3 & 6.7 \\
Spisula solida & 55860 & 89.3 & 305531.8 & 91.8 \\
Total & 62538 & 73.4 & 332702.0 & 84.8 \\
TARGET SPECIES (<MLS) & & & & \\
Chamelea gallina & 297 & 0.3 & 990.9 & 0.3 \\
Donax trunculus & 455 & 0.5 & 824.2 & 0.2 \\
Spisula solida & 18126 & 21.3 & 45727.3 & 11.7 \\
Total & 18878 & 22.1 & 47542.4 & 12.1 \\
BYCATCH SPECIES & & & & \\
Nemertea & 1 & 0.0 & 1.5 & 0.0 \\
Annelida & 35 & 0.0 & 7.9 & 0.0 \\
Mollusca & 549 & 0.6 & 3609.8 & 0.9 \\
Arthropoda & 2863 & 3.4 & 6025.2 & 1.5 \\
Echinodermata & 386 & 0.5 & 2253.7 & 0.6 \\
Chordata & 7 & 0.0 & 256.3 & 0.1 \\
Total & 3841 & 4.5 & 12154.4 & 3.1 \\
Total catch & 85257 & 100.0 & 392398.8 & 100.0 \\
Total bycatch & 22719 & 26.6 & 59696.8 & 15.2 \\
\hline
\end{tabular}

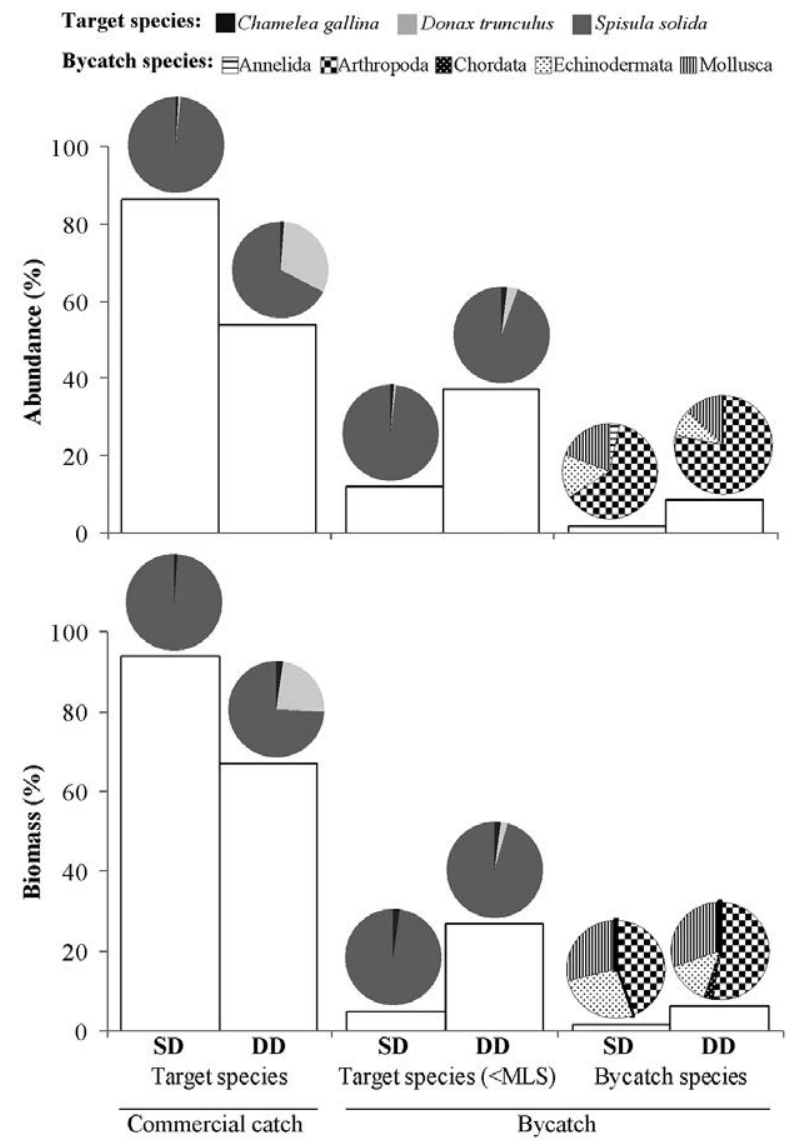

Fig. 3. - Comparison of the abundance and biomass of the catches of the target species (Spisula solida, Chamelea gallina and Donax trunculus) and bycatch (target species $<$ MLS and bycatch species) using SDredge and DDredge.

followed by Malacostraca (11 species) and Gastropoda (6 species).

The comparison of the catches of the target species (C. gallina, D. trunculus and S. solida) above and below the MLS (25 mm shell length) and bycatch species is presented in Figure 3. As expected, the abundances of commercial catches of both dredge types $\quad($ SDredge $=86.5 \%$; DDredge $=54.0 \%)$ and biomass (SDredge $=93.7 \%$; DDredge $=67.1 \%$ ) were clearly higher than those of the bycatch (target species $<$ MLS + bycatch species). Among the target species, $S$. solida was predominant in both abundance (SDredge $=98.6 \%$; DDredge $=67.5 \%$ ) and biomass (SDredge $=98.2 \%$; DDredge $=74.3 \%)$, followed at a distance by $D$. trunculus and by $C$. gallina. Also, as was predictable, catches of $D$. trunculus by the targeted gear (DDredge, $31.6 \%$ of abundance and $23.9 \%$ of biomass) were clearly higher than those using the other dredge type (SDredge, $0.7 \%$ abundance and $0.7 \%$ biomass) (Fig. 3). Regarding the bycatch, DDredge invariably caught more target species $<$ MLS $(37.2 \%$ of abundance and $26.8 \%$ of biomass) and bycatch species $(8.7 \%$ of abundance and $6.2 \%$ of biomass) than SDredge. Once again, $S$. solida clearly predominated among the target species <MLS in both abundance (SDredge $=98.8 \%$; DDredge $=94.7 \%$ ) and biomass $($ SDredge $=97.8 \%$; DDredge $=95.6 \%)$. Among the by- 
Table 3. - Mean abundance (number of individuals) of target species, undersized target species (<MLS) and bycatch species caught using two types of bivalve dredges (SDredge and Ddredge) in the fishing surveys performed along the Algarve coast, southern Portugal.

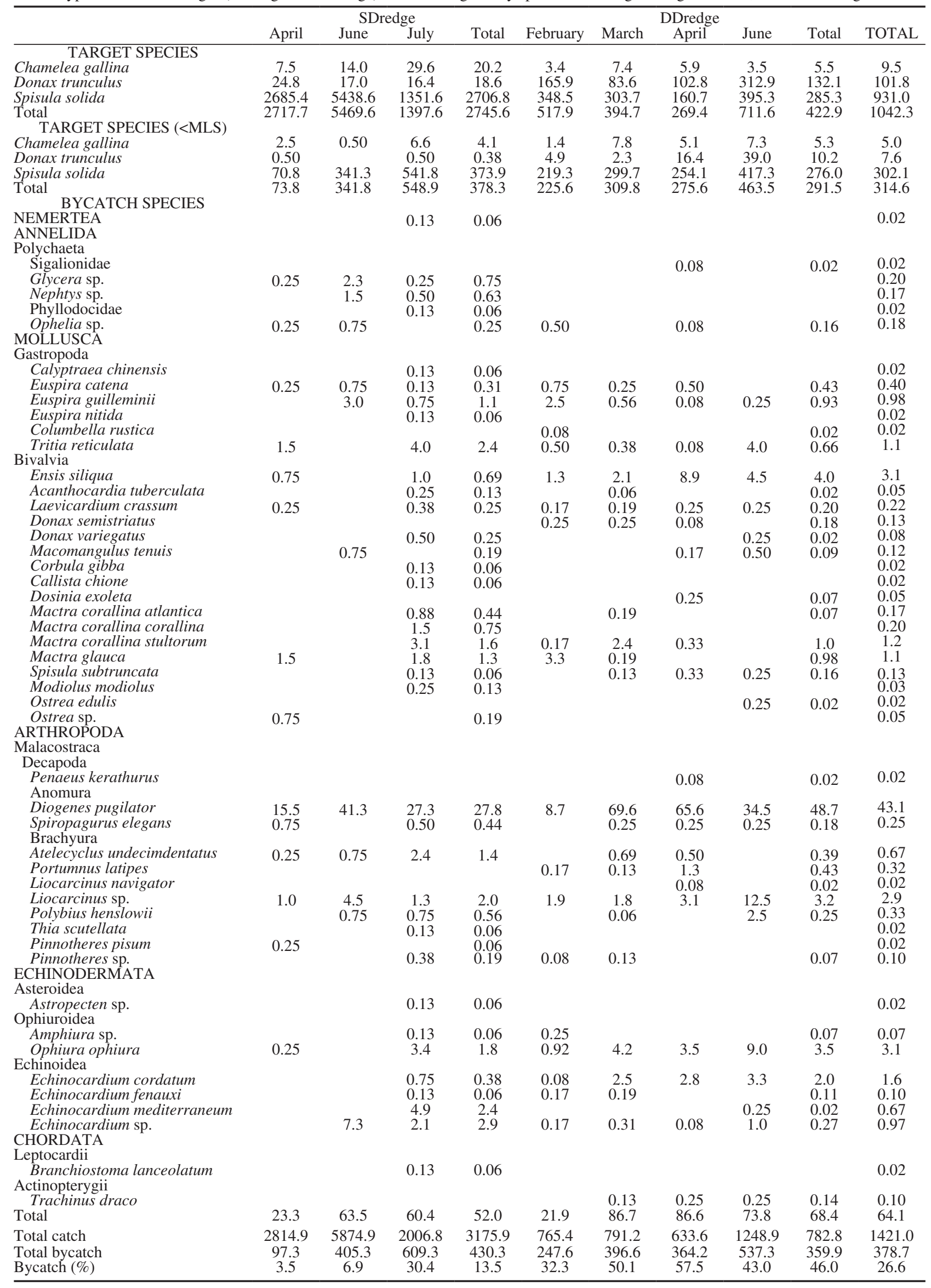


Table 4. - Mean biomass ( $\mathrm{kg})$ of target species, undersized target species $(<\mathrm{MLS})$ and bycatch species caught using two types of bivalve dredges (SDredge and Ddredge) in the fishing surveys performed along the Algarve coast (southern Portugal).

\begin{tabular}{|c|c|c|c|c|c|c|c|c|c|c|}
\hline & \multirow[b]{2}{*}{ April } & \multicolumn{2}{|c|}{ SDredge } & \multicolumn{7}{|c|}{ DDredge } \\
\hline & & June & July & Total & February & March & April & June & Total & TOTAL \\
\hline TARGET SPECIES & & & & & & & & & & \\
\hline Chamelea gallina & 62.9 & 94.5 & 279.2 & 178.9 & $\begin{array}{r}28.1 \\
5067\end{array}$ & 62.8 & 51.2 & 28.6 & 47.1 & 82.2 \\
\hline $\begin{array}{l}\text { Donax trunculus } \\
\text { Spisula solida }\end{array}$ & $\begin{array}{c}165.7 \\
18379.9\end{array}$ & $\begin{array}{c}61.6 \\
25128.7\end{array}$ & $\begin{array}{r}92.9 \\
8238.4\end{array}$ & $\begin{array}{c}103.1 \\
14996.4\end{array}$ & $\begin{array}{c}596.7 \\
1732.4\end{array}$ & $\begin{array}{l}322.1 \\
1609.9\end{array}$ & $\begin{array}{l}378.4 \\
894.8\end{array}$ & $\begin{array}{r}933.6 \\
20765\end{array}$ & $\begin{array}{l}467.9 \\
14907\end{array}$ & $\begin{array}{l}370.6 \\
50922\end{array}$ \\
\hline $\begin{array}{l}\text { Total } \\
\text { TARGET SPECIES (<MLS) }\end{array}$ & 18608.5 & 25284.8 & 8610.1 & 15278.4 & 2357.2 & 1994.7 & 1324.3 & 3038.7 & 2005.6 & 5545.0 \\
\hline Chamelea gallina & 11.1 & 1.8 & 26.2 & 16.4 & 5.8 & 23.8 & 17.0 & 18.5 & 16.6 & 16.5 \\
\hline Donax trunculus & 0.53 & & 0.41 & 0.34 & 9.0 & 2.7 & 31.3 & 72.9 & 18.6 & 13.7 \\
\hline Spisula solida & 243.4 & 1131.1 & 823.2 & 755.2 & 596.6 & 853.8 & 688.7 & 1139.60 & 764.6 & 762.1 \\
\hline Total BYCATCH SPECIES & 255.1 & 1133.0 & 849.9 & 771.9 & 611.4 & 880.3 & 737.1 & 1231.0 & 799.8 & 792.4 \\
\hline $\begin{array}{l}\text { NEMERTEA } \\
\text { ANNELIDA }\end{array}$ & & & 0.19 & 0.09 & & & & & & 0.03 \\
\hline Polychaeta & & & & & & & & & & \\
\hline Sigalionidae & & & & & & & 0.03 & & 0.01 & 0.01 \\
\hline $\begin{array}{l}\text { Glycera sp. } \\
\text { Nephtys sp. }\end{array}$ & 0.10 & 0.18 & 0.11 & 0.13 & & & & & & 0.03 \\
\hline Phyllodocidae & & & 0.01 & 0.01 & & & & & & $\begin{array}{l}0.05 \\
0.00\end{array}$ \\
\hline Ophelia sp. & 0.03 & 0.05 & & 0.02 & 0.16 & & 0.03 & & 0.05 & 0.04 \\
\hline MOLLUSCA & & & & & & & & & & \\
\hline $\begin{array}{l}\text { Gastropoda } \\
\text { Calyptraea chinensis }\end{array}$ & & & 001 & 001 & & & & & & \\
\hline Euspira catena & 1.2 & 1.3 & $\begin{array}{l}0.01 \\
0.36\end{array}$ & 0.80 & 1.7 & 0.99 & 17 & & 13 & 0.00 \\
\hline $\begin{array}{l}\text { Euspira guilleminii } \\
\text { Euspira nitida }\end{array}$ & & 7.1 & $\begin{array}{l}2.5 \\
1.5\end{array}$ & 3.0 & 5.2 & 1.6 & 0.18 & 0.58 & 2.1 & $\begin{array}{l}1.1 \\
2.3 \\
0.19\end{array}$ \\
\hline Columbella rustica & & & & & 0.10 & & & & 0.03 & 0.02 \\
\hline Tritia reticulata & 4.4 & & 10.5 & 6.3 & 0.96 & 0.66 & 0.14 & 9.1 & 1.4 & 2.7 \\
\hline Bivalvia & & & & & & & & & & \\
\hline $\begin{array}{l}\text { Ensis siliqua } \\
\text { Acanthocardia tuberculata }\end{array}$ & 5.1 & & $\begin{array}{l}4.4 \\
4.5\end{array}$ & $\begin{array}{l}3.4 \\
2.3\end{array}$ & 6.0 & $\begin{array}{l}7.1 \\
0.46\end{array}$ & 38.6 & 16.9 & 16.3 & 12.9 \\
\hline Laevicardium crassum & 11.6 & & 19.6 & 12.7 & 4.8 & $\begin{array}{l}4.40 \\
4.9\end{array}$ & 6.8 & 11.2 & 6.0 & $\begin{array}{l}0.13 \\
7.8\end{array}$ \\
\hline Donax semistriatus & & & & & 0.64 & 0.64 & 0.21 & & 0.47 & 0.34 \\
\hline Donax variegatus & & & 2.6 & 1.3 & & & & 0.68 & 0.06 & 0.40 \\
\hline Macomangulus tenuis & & 0.05 & & 0.01 & & & 0.18 & 0.23 & 0.07 & 0.06 \\
\hline Corbula gibba & & & 0.01 & 0.01 & & & & & & 0.00 \\
\hline $\begin{array}{l}\text { Callista chione } \\
\text { Dosinia exoleta }\end{array}$ & & & 3.7 & 1.9 & & & & & & 0.50 \\
\hline $\begin{array}{l}\text { Dosinia exoleta } \\
\text { Mactra corallina atlantica }\end{array}$ & & & & & & & 3.9 & & 1.1 & 0.78 \\
\hline & & & 2.1 & 1.0 & & 1.1 & & & 0.41 & 0.58 \\
\hline $\begin{array}{l}\text { Mactra corallina corallina } \\
\text { Mactra corallina stultorum }\end{array}$ & & & 24.5 & $\begin{array}{r}5.5 \\
12.2\end{array}$ & 1.6 & 15.6 & 27 & & 69 & 1.5 \\
\hline Mactra glauca & 40.0 & & 18.9 & $\begin{array}{ll}12.2 \\
19.4\end{array}$ & $\begin{array}{l}1.0 \\
67.1\end{array}$ & $\begin{array}{l}10.0 \\
1.6\end{array}$ & 2.1 & & $\begin{array}{l}0.9 \\
18.9\end{array}$ & $\begin{array}{l}8.3 \\
19.0\end{array}$ \\
\hline Spisula subtruncata & & & 0.31 & 0.16 & & 0.35 & 0.86 & 0.70 & 0.43 & 0.35 \\
\hline Modiolus modiolus & & & 0.14 & 0.07 & & & & & & 0.02 \\
\hline Ostrea edulis & 86 & & & & & & & 0.95 & 0.09 & 0.06 \\
\hline $\begin{array}{l}\text { Ostrea sp. } \\
\text { ARTHROPODA }\end{array}$ & 8.6 & & & 2.1 & & & & & & 0.57 \\
\hline $\begin{array}{l}\text { ARTHROPODA } \\
\text { Malacostraca }\end{array}$ & & & & & & & & & & \\
\hline Decapoda & & & & & & & & & & \\
\hline Penaeus kerathurus & & & & & & & 1.1 & & 0.30 & 0.22 \\
\hline $\begin{array}{l}\text { Anomura } \\
\text { Diogenes pugilator }\end{array}$ & 43.4 & 106.3 & 65.3 & 70.1 & 12.2 & 118.1 & 103.7 & 50.8 & 79.1 & 76.7 \\
\hline Spiropagurus elegans & 3.6 & & 1.2 & 1.5 & & 0.83 & 1.4 & 3.4 & 0.99 & 1.1 \\
\hline $\begin{array}{l}\text { Brachyura } \\
\text { Atelecyclus undecimdentatus }\end{array}$ & 8.1 & 22.2 & 48.2 & 317 & & 117 & 37 & & 53 & 123 \\
\hline Portumnus latipes & & & & & 0.40 & 0.23 & 2.7 & & 0.93 & 0.68 \\
\hline Liocarcinus navigator & & & & & & & 0.23 & & 0.06 & 0.05 \\
\hline Liocarcinus sp. & 1.1 & 7.3 & 2.9 & 3.6 & 3.3 & 4.7 & 5.8 & 26.5 & 6. & 5.8 \\
\hline $\begin{array}{l}\text { Polybius henslowii } \\
\text { Thia scutellata }\end{array}$ & & & $\begin{array}{l}10.2 \\
0.28\end{array}$ & $\begin{array}{l}5.6 \\
0.14\end{array}$ & & & & & 2 & $\begin{array}{r}3.5 \\
0.04\end{array}$ \\
\hline Pinnotheres pisum & 0.03 & & & 0.01 & & & & & & 0.00 \\
\hline Pinnotheres sp. & & & 0.04 & 0.02 & 0.01 & 0.01 & & & 0.00 & 0.01 \\
\hline ECHINODERMATA & & & & & & & & & & \\
\hline $\begin{array}{l}\text { Asteroidea } \\
\quad \text { Astropecten sp. }\end{array}$ & & & 46 & 23 & & & & & & \\
\hline $\begin{array}{l}\text { Astropecten sp. } \\
\text { Ophiuroidea }\end{array}$ & & & 4.6 & 2.3 & & & & & & 0.61 \\
\hline Amphiura sp. & & & 0.03 & 0.01 & 0.04 & & & & 0.01 & 0.01 \\
\hline Ophiura ophiura & 0.88 & & 1.7 & 1.1 & 0.71 & 2.1 & 1.7 & 5.1 & 1.9 & 1.7 \\
\hline Echinoidea & & & & & & & & & & \\
\hline Echinocardium cordatum & & & 8.9 & 4.4 & 1.4 & 20.2 & 37.1 & 44.1 & 21.9 & 17.2 \\
\hline Echinocardium fenauxi & & & 2.7 & 1.3 & 0.38 & 0.37 & & & 0.24 & 0.53 \\
\hline $\begin{array}{l}\text { Echinocardium mediterraneum } \\
\text { Echinocardium } \mathrm{sp}\end{array}$ & & 68.6 & $\begin{array}{l}04.0 \\
18.0\end{array}$ & 26.3 & 016 & 23 & 032 & 1.7 & 0.15 & 8.7 \\
\hline CHORDATA & & & & & 0.10 & 2.3 & 0.32 & & & \\
\hline Leptocardii & & & & & & & & & & \\
\hline Branchiostoma lanceolatum & & & 0.04 & 0.02 & & & & & & 0.01 \\
\hline Actinopterygii & & & & & & & & & & \\
\hline $\begin{array}{l}\text { Trachinus draco } \\
\text { Total }\end{array}$ & 128.2 & 214.9 & 335.7 & 253.7 & & $\begin{array}{c}4.1 \\
200.6\end{array}$ & $\begin{array}{c}14.6 \\
227.6\end{array}$ & $\begin{array}{c}3.6 \\
218.5\end{array}$ & $\begin{array}{c}5.8 \\
184.0\end{array}$ & $\begin{array}{c}4.3 \\
202.6\end{array}$ \\
\hline Total catch & 18991.8 & 26632.7 & 9795.7 & 16304.0 & 3075.4 & 3075.6 & 2289.0 & 4488.2 & 2989.4 & 6540.0 \\
\hline Total bycatch & 383.2 & 1347.9 & 1185.6 & 1025.6 & 718.3 & 1080.9 & 964.7 & 1449.5 & 983.8 & 994.9 \\
\hline Bycatch (\%) & 2.0 & 5.1 & 12.1 & 6.3 & 23.4 & 35.1 & 42.1 & 32.3 & 32.9 & 15.2 \\
\hline Debris & 4464.0 & 3029.1 & 8100.3 & 5923.4 & 3769.9 & 2660.2 & 1012.0 & 10132.4 & 3192.6 & 3920.8 \\
\hline Debris (\%) & 19.0 & 10.2 & 45.3 & 26.6 & 55.1 & 46.4 & 30.7 & 69.3 & 51.6 & 37.5 \\
\hline
\end{tabular}



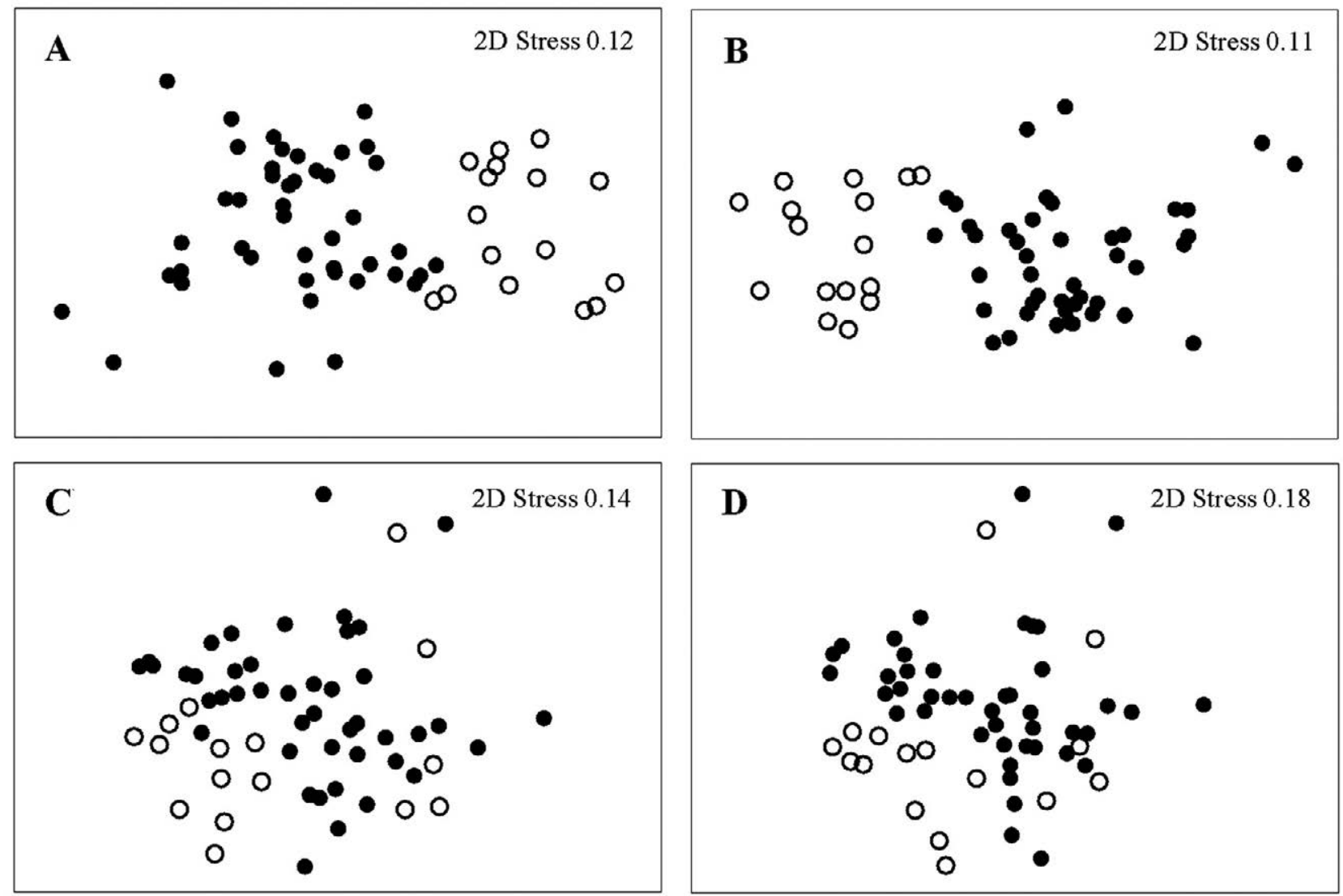

Fig. 4. - Multidimensional Scaling (MDS) ordination analysis (Bray-Curtis similarity, square root transformed) of the total catches composition in abundance (A) and biomass (B) and of the bycatch composition in abundance (C) and biomass (D) using SDredge (open circles) and DDredge (full circles).

catch species, arthropods were predominant in both dredge types in both abundance (SDredge $=62.7 \%$; DDredge $=78.2 \%$ ) and biomass (SDredge $=44.4 \%$; DDredge $=52.1 \%$ ), followed by molluscs and echinoderms, which displayed lower proportions in abundance than in biomass (Fig. 3).

The number of taxa collected in the four fishing surveys (16 tows) performed using SDredge (43 taxa) accounted for $59.6 \%$ of the individuals and $66.5 \%$ of the total weight caught using both types of dredge during all the surveys, whereas the 11 surveys (44 tows) using DDredge (37 taxa) corresponded to the remaining $40.4 \%$ of the individuals and $33.5 \%$ of the total weight (Tables 3 and 4). Overall, bivalves, malacostracans and echinoids were the most abundant classes, and the three target bivalve species (mostly S. solida, followed at a distance by $C$. gallina and D. truncu$l u s)$ and the small hermit crab (Diogenes pugilator) were the most frequent species caught by SDredge in terms of both abundance and biomass. Similarly, the commercial bivalve species (mostly $S$. solida and $D$. trunculus, followed at a distance by $C$. gallina) and $D$. pugilator clearly predominated in both the abundance and biomass caught by SDredge (Tables 3 and 4).

On average, the bycatch rate using SDredge $(13.5 \%$ in number and $6.3 \%$ in weight) was much lower than that using DDredge (46.0\% in number and $32.9 \%$ in weight) (Tables 3 and 4), with debris also representing a smaller proportion of the total weight in the hauls of SDredge
(26.6\%) than in those of DDredge (51.6\%) (Table 4). In both types of dredge, commercially undersized $S$. solida $(<\mathrm{MLS})$ and $D$. pugilator were clearly the most frequent bycatch species in both number and weight (Tables 3 and 4). In addition to these species, the bycatch of SDredge also comprised considerable abundances of undersized C. gallina, Echinocardium sp. and Echinocardium mediterraneum, as well as substantial biomasses of $E$. mediterraneum, Atelecyclus undecimdentatus and undersized C. gallina. In addition, the bycatch of DDredge also included abundant undersized $D$. trunculus and $C$. gallina, Ensis siliqua and Ophiura ophiura, together with substantial biomasses of Echinocardium cordatum, Mactra glauca, undersized D. trunculus and C. gallina (Tables 3 and 4).

The multidimensional scaling (MDS) analysis of the total catch composition in abundance and biomass clearly identified two separate groups corresponding to each type of dredge and almost without overlapping (Fig. 4A, B). The ANOSIM test corroborated this trend by detecting significant differences in both the abundance $(\mathrm{R}=0.647, \mathrm{p}<0.01)$ and biomass $(\mathrm{R}=0.734$, $\mathrm{p}<0.01)$ caught by each type of dredge. SIMPER analysis estimated average dissimilarities between dredges of $51.9 \%$ for abundance and $56.2 \%$ for biomass, with S. solida (57.4\% of abundance; $65.3 \%$ of biomass), $D$. trunculus (12.0\% of abundance; $7.7 \%$ of biomass) and D. pugilator $(6.2 \%$ of abundance; $3.0 \%$ of biomass) being the main contributors to these differences. On the 
other hand, the MDS analysis applied to the bycatch composition in abundance and biomass displayed a lower capacity to discriminate samples from the two types of dredge (Fig. 4C, D), revealing a more similar abundance and biomass in the bycatch of SDredge and DDredge, as confirmed by the significant but lower statistical significance levels obtained in the ANOSIM test in terms of both abundance $(\mathrm{R}=0.284, \mathrm{p}=0.025)$ and biomass $(\mathrm{R}=0.250, \mathrm{p}=0.045)$ of the bycatch of each type of dredge. Additionally, the ANOVAs performed to compare the bycatch proportion between types of dredge detected highly significant differences in both the abundance $(\mathrm{K}-\mathrm{W}: \mathrm{H}=19.181, \mathrm{p}<0.001)$ and biomass ( $\mathrm{K}-\mathrm{W}: \mathrm{H}=30.063, \mathrm{p}<0.001)$ of the individuals caught as bycatch using SDredge and DDredge.

\section{Damage and mortality}

The comparison of the damage and mortality rates inflicted by the two types of dredges in the commercial catches (S. solida, C. gallina and D. trunculus) and bycatch (target species $<$ MLS and bycatch species) is presented in Figure 5. The damage and mortality rates of both SDredge and DDredge were considerably higher in the bycatch species than in the target bivalve species $(S$. solida, C. gallina and D. trunculus), including both commercial catches and undersized individuals ( $<$ MLS). In general, the damage rates induced by SDredge (target species $=0.9 \%$; target species $<\mathrm{MLS}=0.8 \%$ ) were lower than those induced by DDredge (target species $=3.1 \%$; target species $<\mathrm{MLS}=1.1 \%$ ), except for the remaining bycatch species, which were more frequently damaged by SDredge $(26.3 \%)$ than by DDredge $(22.4 \%)$. Accordingly, the mortality rates caused by SDredge (target species $=0.8 \%$; target species $<\mathrm{MLS}=0.6 \%$ ) were also lower than those caused by DDredge (target species $=2.6 \%$; target species $<\mathrm{MLS}=0.9 \%$ ), while the mortality inflicted in the remaining bycatch species was higher for SDredge $(15.5 \%)$ than for DDredge (12.2\%) (Fig. 5). There was no significant correlation between the weight of debris collected by the dredges and the damage rate inflicted on the catches $(r=-0.078$, $\mathrm{p}>0.05)$, whereas highly significant differences were

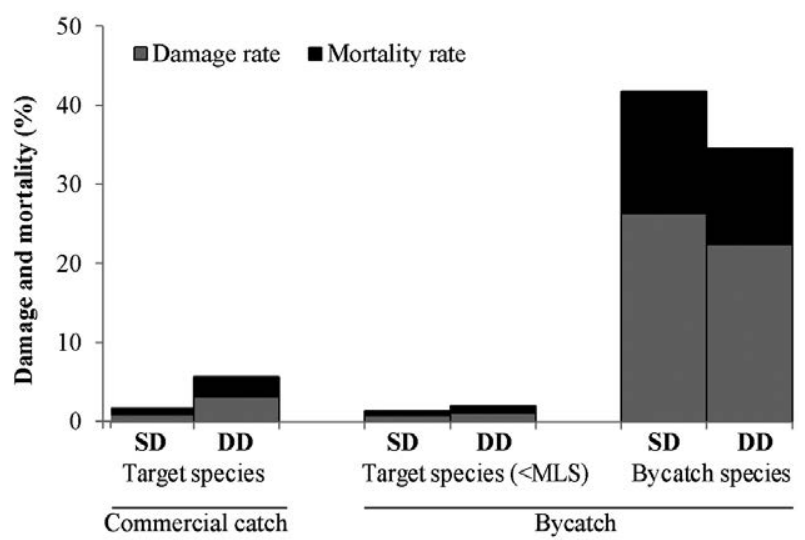

Fig. 5. - Comparison of the damage and mortality rates in the catches of the target species (Spisula solida, Chamelea gallina and Donax trunculus) and bycatch (target species $<$ MLS and bycatch species) using SDredge and DDredge. detected in the mortality rate between SDredge and DDredge (K-W: $\mathrm{H}=10.845$, $\mathrm{p}<0.001)$.

Detailed information on the damage and mortality of all the taxa caught using the two types of dredges (Table 5) further confirms that the overall damage and mortality rates were lower for SDredge $(1.3 \%$ and $1.0 \%$ of total catches, respectively) than for DDredge (4.0\% and $2.8 \%$ of total catches, respectively). Among the commercial bivalves caught by SDredge, S. solida displayed the lowest rates of damage $(0.78 \%)$ and mortality $(0.73 \%)$, whereas $D$. trunculus displayed the highest rates of damage (11.4\%) and mortality (9.7\%). In the commercial catches using DDredge, C. gallina was the most affected and injured $(5.4 \%$ and $5.0 \%$, respectively), followed by D. trunculus $(4.7 \%$ and $3.7 \%$, respectively). Regarding the undersized target species $(<\mathrm{MLS})$, SDredge and DDredge displayed roughly the same trend in both damage and mortality rates $(D$. trunculus $>C$. gallina $>S$. solida), although for D. trunculus the rates were clearly higher using SDredge than using DDredge. In general, target species $<$ MLS were less affected by dredging operations than commercial catches, and independently of the type of dredge, $S$. solida was invariably the least susceptible target species (including $<\mathrm{MLS}$ and commercial catches) to damage and mortality inflicted during dredging. Moreover, SDredge inflicted lower damage and mortality on its target species ( $S$. solida), whereas DDredge caused more similar damage and mortality to both its target species (D. trunculus) and other commercial catches (C. gallina and S. solida) (Table 5).

Among all bivalve species caught as bycatch, Ensis siliqua was clearly the most sensitive species to dredging impacts, showing $100 \%$ mortality in both SDredge and DDredge. In addition, Callista chione, Laevicardium crassum and Macomangulus tenuis displayed $100 \%$ mortality only for SDredge, whereas D. variegatus displayed $100 \%$ mortality only for DDredge. The genus Mactra invariably showed high damage and mortality rates independently of the type of dredge, with over $75 \%$ damage and $60 \%$ mortality in both SDredge and DDredge. The five gastropod species caught by SDredge suffered very low damage (Tritia reticulata $=10.5 \%$ ) and no mortality, whereas the four gastropod species caught by DDredge displayed highly variable mortality rates (T. reticulata $=0 \%$; Columbella rustica $=100 \%$ ) (Table 5).

The most abundant bycatch species caught during dredging surveys (D. pugilator) exhibited low damage and mortality rates in both SDredge $(6.7 \%$ and $0 \%$, respectively) and DDredge (4.8\% and $0.14 \%$, respectively). The serpent star (Ophiura ophiura) showed very high damage in both types of dredges $(82.1 \%$ and $92.9 \%$ ) but remarkably low mortality (0\% and $11.5 \%)$. In both SDredge and DDredge, Liocarcinus sp. showed low damage (25.0\% and $38.8 \%$, respectively) and even less mortality ( $0 \%$ and $5.8 \%$, respectively). Most echinoids were highly sensitive to dredging, with damage and mortality rates over $50 \%$ (e.g. Echinocardium sp. $=56.5 \%$ damage and mortality in SDredge; Echinocardium cordatum $=59.8 \%$ damage and $51.7 \%$ mortality in DDredge). Among the lower abundant bycatch 
Table 5. - Mean number and proportion of damaged and dead individuals per taxon caught using two types of bivalve dredges (SDredge and Ddredge) in the fishing surveys performed along the Algarve coast (southern Portugal).

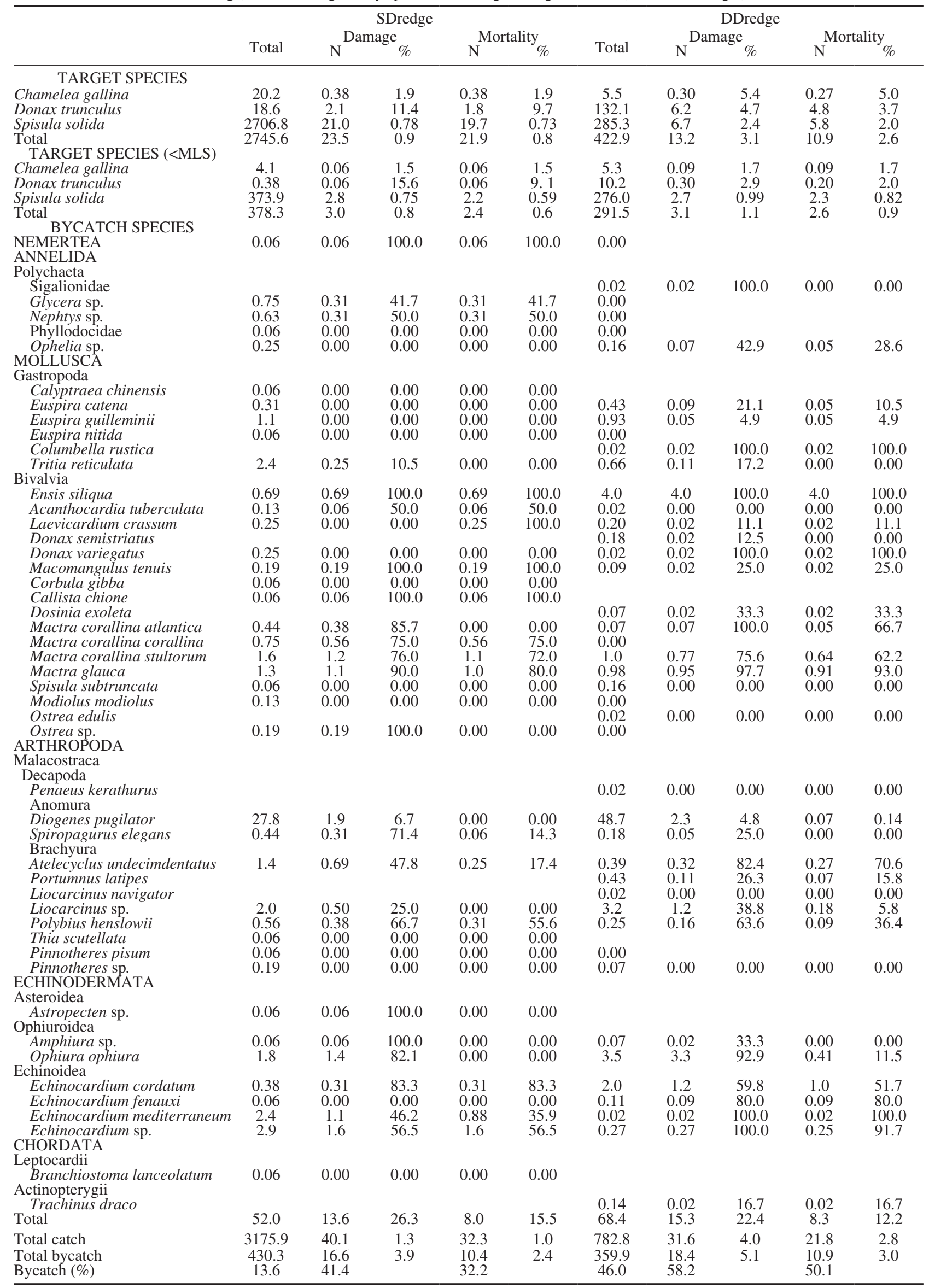


Table 6. - Survival experiments performed in the containment facilities with diverse taxa caught as target or bycatch species during bivalve dredging.

\begin{tabular}{|c|c|c|c|c|c|c|c|c|c|c|c|c|c|c|c|c|c|c|c|c|}
\hline & & & & & & & & & ortal & ty ( & & & & & & & & & & \\
\hline & $\begin{array}{l}\text { Num } \\
D_{0}\end{array}$ & $\begin{array}{r}\text { nber } \\
D_{1}\end{array}$ & $\mathrm{D}_{0}^{5}$ & $\mathrm{D}_{1}$ & $\mathrm{D}_{0}^{1}$ & $\mathrm{~d}_{1}$ & $\mathrm{D}_{0}^{2}$ & $d$ & $\mathrm{D}_{0}^{3}$ & $D_{1}$ & $\mathrm{D}_{0}^{4}$ & $\mathrm{D}_{1}$ & $\mathrm{D}_{0}^{5}$ & $\mathrm{~d}_{1}$ & $\mathrm{D}_{0}^{7}$ & $\mathrm{~d}$ & $\begin{array}{c}\text { Survive } \\
\mathrm{D}_{0}\end{array}$ & $\begin{array}{l}\text { ors (N) } \\
D_{1}\end{array}$ & Survival & $\begin{array}{l}1 \text { rate } \\
\mathrm{D}_{1}\end{array}$ \\
\hline CATCHES & & & & & & & & & & & & & & & & & & & & \\
\hline Target species & & & & & & & & & & & & & & & & & & & & \\
\hline Chamelea gallina & 20 & & & & & & & & & & & & & & & & 20 & & 100.0 & \\
\hline Donax trunculus & 168 & 66 & & & & 5 & 2 & 32 & 3 & 3 & 3 & 7 & 1 & 1 & 1 & 2 & 158 & 16 & 94.0 & 24.2 \\
\hline Spisula solida & 103 & 5 & & & & & 2 & 1 & & & 6 & 1 & & & 6 & & 89 & 3 & 86.4 & 60.0 \\
\hline Total & 291 & 71 & 0 & 0 & 0 & 5 & 4 & 33 & 3 & 3 & 9 & 8 & 1 & 1 & 7 & 2 & 267 & 19 & 91.8 & 26.8 \\
\hline $\begin{array}{c}\text { BYCATCH } \\
\text { Target species }(<\mathrm{MLS})\end{array}$ & & & & & & & & & & & & & & & & & & & & \\
\hline Donax trunculus & 168 & 26 & & & & & 1 & 8 & & 1 & 1 & 3 & & & 1 & 1 & 165 & 13 & 98.2 & 50.0 \\
\hline Spisula solida & 199 & & & & & & 1 & & & & 2 & & & & 1 & & 195 & & 98.0 & \\
\hline $\begin{array}{l}\text { Total } \\
\text { BYCATCH SPECIES }\end{array}$ & 367 & 26 & 0 & 0 & 0 & 0 & 2 & 8 & 0 & 1 & 3 & 3 & 0 & 0 & 2 & 1 & 360 & 13 & 98.1 & 50.0 \\
\hline ANNELIDA & & & & & & & & & & & & & & & & & & & & \\
\hline Polychaeta & & & & & & & & & & & & & & & & & & & & \\
\hline Glycera sp. & & 1 & & & & 1 & & & & & & & & & & & & 0 & & 0.0 \\
\hline Ophelia sp. & 1 & & 1 & & & & & & & & & & & & & & 0 & & 0.0 & \\
\hline $\begin{array}{l}\text { MOLLUSCA } \\
\text { Gastropoda }\end{array}$ & & & & & & & & & & & & & & & & & & & & \\
\hline $\begin{array}{l}\text { Gastropoda } \\
\text { Euspira catena }\end{array}$ & & & & & & & & & & & & & & & & & & & & \\
\hline $\begin{array}{l}\text { Euspira catena } \\
\text { Tritia reticulata }\end{array}$ & 6 & & & & & & & & & & & & & & & & 6 & & 100.0 & \\
\hline $\begin{array}{l}\text { Tritia reticulata } \\
\text { Bivalvia }\end{array}$ & 8 & & & & & & & & & & & & & & & & 8 & & 100.0 & \\
\hline $\begin{array}{l}\text { Bivalvia } \\
\text { Fnsis siliaug }\end{array}$ & & & & & & & & & & & & & & & & & & & & \\
\hline Ensis siliqua & & 1 & & 1 & & & & & & & & & & & & & & 0 & & 0.0 \\
\hline Laevicardium crassum & 1 & & & & & & & & & & & & & & & & 1 & & 100.0 & \\
\hline Donax semistriatus & 1 & & & & & & & & & & & & & & & & 1 & & 100.0 & \\
\hline Ostrea edulis & 3 & & & & & & & & & & & & & & & & 3 & & 100.0 & \\
\hline ARTHROPODA & & & & & & & & & & & & & & & & & & & & \\
\hline Malacostraca & & & & & & & & & & & & & & & & & & & & \\
\hline Decapoda & & & & & & & & & & & & & & & & & & & & \\
\hline Penaeus kerathurus & & 2 & & 2 & & & & & & & & & & & & & & 0 & & 0.0 \\
\hline Anomura & & & & & & & & & & & & & & & & & & & & \\
\hline Diogenes pugilator & 284 & 4 & & & & 1 & 6 & 3 & & & & & & & 3 & & 275 & 0 & 96.8 & 0.0 \\
\hline Spiropagurus elegans & 1 & 1 & & & & & & & & & & & & & & 1 & 1 & 0 & 100.0 & 0.0 \\
\hline Brachyura & & & & & & & & & & & & & & & & & & & & \\
\hline Atelecyclus undecimdentatus & 1 & & & & & & & & & & & & & & & & 1 & & 100.0 & \\
\hline Portumnus latipes & 14 & 4 & & & & & 1 & 2 & & 1 & 1 & & & & 1 & & 11 & 1 & 78.6 & 25.0 \\
\hline Liocarcinus sp. & 18 & 14 & 1 & 3 & & & 2 & 3 & & & & & & & 2 & & 13 & 8 & 72.2 & 57.1 \\
\hline Thia scutellata & 1 & & & & & & & & & & & & & & & & 1 & & 100.0 & \\
\hline Pinnotheres pisum & 1 & & 1 & & & & & & & & & & & & & & 0 & & 0.0 & \\
\hline ECHINODERMATA & & & & & & & & & & & & & & & & & & & & \\
\hline Ophiuroidea & & & & & & & & & & & & & & & & & & & & \\
\hline Amphiura sp. & & 1 & & & & & & & & 1 & & & & & & & & 0 & & 0.0 \\
\hline Ophiura ophiura & 3 & & & & & & & & & & & & & & & & 3 & & 100.0 & \\
\hline Echinoidea & & & & & & & & & & & & & & & & & & & & \\
\hline $\begin{array}{l}\text { Echinocardium cordatum } \\
\text { CHORDATA }\end{array}$ & 16 & 2 & & & & & 15 & 2 & 1 & & & & & & & & 0 & 0 & 0.0 & 0.0 \\
\hline Leptocardii & & & & & & & & & & & & & & & & & & & & \\
\hline Branchiostoma lanceolatum & 1 & & & & 1 & & & & & & & & & & & & 0 & & 0.0 & \\
\hline Actinopterygii & & & & & & & & & & & & & & & & & & & & \\
\hline Ammodytes tobianus & 1 & & 1 & & & & & & & & & & & & & & 0 & & 0.0 & \\
\hline Total & 361 & 30 & 4 & 6 & 1 & 2 & 24 & 10 & 1 & 2 & 1 & 0 & 0 & 0 & 6 & 1 & 324 & 9 & 89.8 & 30.0 \\
\hline Total & 1019 & 127 & 4 & 6 & 1 & 7 & 30 & 51 & 4 & 6 & 13 & 11 & 1 & 1 & 15 & 4 & 951 & 41 & 93.3 & 32.3 \\
\hline
\end{tabular}

taxa, polychaetes generally exhibited damage and mortality rates below $50 \%$ (Table 5).

\section{Survival experiments}

Among the diverse taxa caught consistently during the bivalve dredging surveys, a total of 1146 macrobenthic organisms $\left(D_{0}=1019 ; D_{1}=127\right)$ were subjected to survival experiments, comprising $362\left(\mathrm{D}_{0}=291 ; \mathrm{D}_{1}=71\right)$ individuals of the target species (C. gallina, D. trunculus and $S$. solida $), 393\left(\mathrm{D}_{0}=367 ; \mathrm{D}_{1}=26\right)$ undersized individuals $(<\mathrm{MLS})$ of the target species and $391\left(\mathrm{D}_{0}=361\right.$; $\mathrm{D}_{1}=30$ ) individuals of the remaining bycatch species (Table 6). Overall, 12.5\% of the individuals showed damage, with the target species displaying higher proportions of injured specimens $\left(D_{1}=24.4 \%\right)$ than un- dersized target species $\left(\mathrm{D}_{1}=7.1 \%\right)$ and other bycatch species $\left(\mathrm{D}_{1}=8.3 \%\right)$. Among the target species, all $C$. gallina were apparently intact $\left(\mathrm{D}_{0}=100 \%\right)$, whereas $D$. trunculus were much more damaged $\left(\mathrm{D}_{1}=39.3 \%\right)$ than $S$. solida $\left(\mathrm{D}_{1}=4.9 \%\right)$. In addition, among the undersized individuals of the target species, all $S$. solida were apparently intact $\left(\mathrm{D}_{0}=100 \%\right)$, while the proportion of slightly damaged $D$. trunculus was $15.5 \%$. In both $D$. trunculus and $S$. solida, most damage was due to partially or totally cut feet. The four most represented taxa among the bycatch species showed highly variable damage rates, namely the small hermit crab $D$. pugilator $\left(\mathrm{D}_{1}=1.4 \%\right)$, the swimming crab Liocarcinus sp. $\left(\mathrm{D}_{1}=77.8 \%\right)$, the heart-urchin E. cordatum $\left(\mathrm{D}_{1}=12.5 \%\right)$ and the Pennant's swimming crab $P$. latipes $\left(\mathrm{D}_{1}=28.6 \%\right)$ (Table 6$)$.

The mean survival rates of the target species 
were noticeably higher for undamaged individuals $\left(\mathrm{D}_{0}=91.8 \%\right)$, ranging from $86.4 \%$ in $S$. solida to $100 \%$ in C. gallina, than for slightly damaged specimens $\left(\mathrm{D}_{1}=26.8 \%\right)$, ranging from $24.2 \%$ in D. trunculus to $60.0 \%$ in S. solida (Table 6). On the other hand, undersized specimens of the target species $(<\mathrm{MLS})$ showed higher survival rates for both intact individuals $\left(\mathrm{D}_{0}\right.$ : D. trunculus $=98.2 \% ; S$. solida $=98.0 \%$ ) and slightly injured individuals $\left(\mathrm{D}_{1}:\right.$ D. trunculus $\left.=50.0 \%\right)$. Regarding the remaining taxa caught as bycatch, most species displayed highly variable survival rates depending on the respective damage score $\left(\mathrm{D}_{0}=89.8 \% ; \mathrm{D}_{1}=30.0 \%\right)$, including the numerically most representative bycatch taxa, namely D. pugilator $\left(\mathrm{D}_{0}=96.8 \% ; \mathrm{D}_{1}=0 \%\right)$, E. cordatum $\left(\mathrm{D}_{0}=0 \% ; \mathrm{D}_{1}=0 \%\right)$, Liocarcinus $\mathrm{sp} .\left(\mathrm{D}_{0}=72.2 \%\right.$; $\left.\mathrm{D}_{1}=57.1 \%\right)$ and $P$. latipes $\left(\mathrm{D}_{0}=78.6 \% ; \mathrm{D}_{1}=25.0 \%\right)$. Undamaged individuals $\left(\mathrm{D}_{0}\right)$ of several taxa showed $100 \%$ survival rate (A. undecimdentatus, D. semistriatus, E. catena, L. crassum, O. ophiura, O. edulis, $S$. elegans, T. scutellata and $T$. reticulata), whereas slightly damaged individuals $\left(\mathrm{D}_{1}\right)$ of other taxa suffered $100 \%$ mortality rate (Amphiura sp., D. pugilator, E. cordatum, E. siliqua, Glycera sp., P. kerathurus and $S$. elegans). In the particular case of the heart urchin $(E$. cordatum), the fact that all individuals died within 2-3 days in captivity might be due to starvation, because no specific food was provided for this type of feeding guild (grazers/deposit feeders). Overall, for all the taxa subjected to the survival experiments, survival rates were $93.3 \%$ in undamaged individuals $\left(\mathrm{D}_{0}\right)$ and $32.3 \%$ in slightly damaged individuals $\left(\mathrm{D}_{1}\right)$ (Table 6).

\section{DISCUSSION}

The assessment of bycatch issues is critical for assessing the sustainability of any fishery. In addition to determining the catch composition, the quantification of bycatch and discard rates allows the efficiency and operational performance of the fishing gear to be measured. The fact that previous studies recorded considerable amounts of bycatch in the bivalve dredge fisheries along the Algarve coast, even exceeding the catch of the target species in late spring and early summer (Gaspar and Chícharo 2007), reinforces the importance of the present study and the need for further investigation on this important subject. Other studies have reported seasonal trends in the bycatch collected by mechanical bivalve dredges: namely an increase in flatfish discards in autumn on the Algarve coast (Palma et al. 2003), possibly associated with greater abundances in benthic communities in this area during this season (Alves et al. 2003), and also higher discards of D. trunculus in spring and summer in the northern Alboran Sea (Urra et al. 2017).

In the present study, the quantification of bycatch using two grid dredges with different technical specifications revealed highly significant differences in the composition of the total catches between types of dredge that were mainly due to the abundance and biomass of the target species ( $S$. solida, C. gallina and D. truncu$l u s)$ and also of the hermit crab (D. pugilator). These clear differences confirm that each type of dredge was developed and is well adjusted to maximize the catch of its target species. Although significant, less evident differences were detected in the composition of the bycatch collected by the two dredges, probably because of the overall similarity of the benthic communities at closely located sampling sites and bathymetries. The bycatch composition was dominated by the presence of commercially undersized individuals of the target species and by benthic species with dimensions and morphological features that prevented their passage through the parallel bars of the grid dredge, such as larger bivalve species, hermit crabs and heart urchins. This is a common issue in fishing gears designed to mechanically preclude the catch according to specimen size. For instance, because smaller individuals escape through the interconnecting steel rings of the dredge, the bycatch composition of the king scallop dredge fishery in the English Channel is dominated by large benthic and demersal fish species (Szostek et al. 2017).

The bycatch rates represented $46.0 \%$ of total catches in abundance and $32.9 \%$ in biomass using DDredge. In the dredge fishery targeting $C$. chione performed in the Setúbal region (western coast of Portugal) a high proportion of bycatch (31\% in number) was also recorded (Gaspar et al. 2001). Significantly lower bycatch rates (13.5\% of total catches in abundance and 6.3\% in biomass) were recorded for SDredge, due to high densities of its target species ( $S$. solida) in the bivalve beds along the Algarve coast. Another study also using a grid dredge to target $S$. solida in the same sampling area reported a mean bycatch rate of $9 \%$ in biomass (Leitão et al. 2009). In addition, previous fishing surveys performed in the same area recorded much higher fishing yields of $S$. solida (957 g/5 min. tow) than of D. trunculus (248 g/5 min. tow), reflecting clear differences in species abundance and density over time (Gaspar et al. 2015). For the same reason but with an opposite trend, low densities of target species were responsible for very high bycatch and discard rates $(\approx 90 \%)$ in the "rapido" trawl scallop (Pecten jacobaeus) fishery in the Adriatic Sea (Pranovi et al. 2001).

In the present study, damage and mortality, which reflect the direct impact of the dredging operations, were predominantly low despite the presence of some sensitive species in the catches. The three bivalve target species (S. solida, C. gallina and D. trunculus) exhibited low damage and mortality rates, $S$. solida being the least affected and $D$. trunculus the most affected by dredging impacts. Likewise, except for $D$. trunculus, which showed slightly higher mortality, the undersized individuals of the remaining target species also displayed fairly low damage and mortality rates. Overall, damage and mortality depend on the operational and technical characteristics of the fishing gears and on some biological and ecological features of the taxa collected as either target catch or bycatch. In particular, bivalve species susceptibility to damage are markedly influenced by their shell morphology and resistance to breakage (the force required to break the shell) (Bergmann et al. 2001, Vasconcelos et al. 2011). Accordingly, bigger damage rates and significantly higher mortality rates in DDredge than in SDredge are 
probably due to the lower proportions of thick-shelled and more resistant bivalves, such as $S$. solida and $C$. gallina, in the catches using DDredge.

In contrast, the pod razor shell (E. siliqua), a thinshelled bivalve that usually burrows shallowly close to the sediment surface but can burrow down to 60 cm deep when disturbed (Gaspar et al. 1998), showed very high mortality rates independently of the type of dredge. Such high mortalities are explained by the difference between the dredge teeth length $(20 \mathrm{~cm})$ and the maximum burrowing depth of E. siliqua $(60 \mathrm{~cm})$, because the perturbation caused by dredging induces deeper burrowing as a self-protective behaviour. Most individuals are hit by the dredge teeth in the upper and middle portions of the shell, suffering severe damage and subsequent mortality (Gaspar et al. 1998). Though it is the third most abundant species caught by both types of dredge, the hermit crab (D. pugilator) showed high resilience to dredging impacts in terms of both damage rate $(<10 \%)$ and mortality rate $(<1 \%$, mainly individuals that abandoned their protective shells). This low sensitivity, coupled with recruitment every four months on the Portuguese coast (Dolbeth et al. 2006), makes this species almost invulnerable to bivalve dredging impacts on the Algarve coast. Swimming crabs (Liocarcinus sp.) also occurred in high abundances but displayed low damage and mortality rates, corroborating previous data gathered using the metallic grid dredge (Gaspar et al. 2003b). However, physiological responses of Liocarcinus depurator to aerial exposure reveal that, although it is not directly lethal, the stress induced by emersion might lead to metabolic disruptions that increase the susceptibility to predation (Bergmann et al. 2001).

Damage and mortality rates of echinoderms confirmed their fragility when subjected to impacts and stress, with the four species of sea urchins (Echinocardium spp.) being highly susceptible to lethal injuries caused by both types of dredge. This previously reported high susceptibility to damage (e.g. Kaiser and Spencer 1995, Gaspar et al. 2003b, Leitão et al. 2009) was attributed to the fact that the fused plates of sea urchins imply low flexibility and high sensitivity to mechanical damage during bivalve dredging (Kaiser and Spencer 1995). By contrast, brittle stars (class Ophiuroidea) exhibited very high damage rates but very low mortality rates. Several studies have confirmed the high resilience of the serpent star (Ophiura ophiura) to bottom fishing, considering that arm damage and breakage induce low mortality due to the high regeneration capacity of this species (e.g. Kaiser and Spencer 1995, Hill et al. 1996, Ramsay et al. 1998), which also relies on its high reproductive resilience to cope with severe damage and consequent mortality (Pranovi et al. 2001). However, Bergmann and Moore (2001) highlighted that fishing-related stress and damage could induce higher susceptibility to bacterial infection and subsequent death in this species.

There is lack of information regarding the survival of bycatch species after discarding (Leitão et al. 2014). In the Portuguese dredge fishery, most discards are invertebrate species (bivalves, gastropods, crustaceans and echinoderms). Depending on the volume of the catches, the specimens caught are sometimes only sorted at the end of the fishing day, which may decrease the survival of discarded individuals (Gaspar and Chícharo 2007). Despite the overall low mortality recorded in this study, dredging-induced stress might cause a slow recovery of the activity of discarded individuals, which thus become more vulnerable to predation (Robinson and Richardson 1998, Chícharo et al. 2002b). However, several authors have reported low rates of indirect mortality in molluscs and crustaceans (Gruffydd 1972, Caddy 1973, Kaiser and Spencer 1995), the two most abundant taxa collected in the present study. Larger individuals in particular are typically more resistant to damage and mortality (Birkett 1959, Medcof and MacPhail 1964, Trewin and Welsh 1972).

In order to estimate survival rates more accurately, captivity experiments were performed in aquaculture facilities during the present study. However, it is assumed that the effect of captivity upon the experimental individuals might lead to an underestimation of survival rates, whereas the exclusion of predation effects might lead to an overestimation (ICES 2014). Based on the arbitrary damage scores used in this study, the high survival rate of undamaged $\left(\mathrm{D}_{0}\right)$ and slightly damaged $\left(D_{1}\right)$ individuals allowed us to infer that in this bivalve dredge fishery discarding can lead to considerable survival rates when catches are sorted immediately after each tow and discarded near the natural beds of the harvested species. One interesting finding of the captivity experiments was the fact that, when subjected to the perturbation and stress during dredging, D. trunculus appears to be faster closing the valves than retracting the foot, so apparently undamaged individuals were actually injured internally, which might jeopardize their likelihood of survival.

The design of the currently used grid dredge allows smaller individuals of both target and bycatch species to escape through the spacing between bars of the grid. However, although the dredges are adapted to the bivalve target species, they retain larger specimens of the bycatch species, which are later hauled, sorted on board and discarded. However, this gear proved much better than the traditional and northern dredges, because it collected a significantly lower amount of unwanted accessory species (Gaspar et al. 2001, 2003b, Leitão et al. 2009). In a strictly scientific approach to the problem of bycatch, high bycatch rates should not be a major problem if most discarded individuals survive (Gaspar and Chícharo 2007), but bycatch is also an ethical, technical, political and economic issue (Hall et al. 2000).

The morphological diversity of the bycatch taxa caught by bivalve dredging requires a dredge design that is efficient, selective and causes low damage to all collected organisms. The current technical design of the metallic grid dredge should be basically maintained and only slight modifications should be introduced, namely by introducing a bycatch reduction device (BRD) in order to allow most bycatch specimens to escape. Despite extensive research confirming significant bycatch reductions due to the adoption of BRDs 

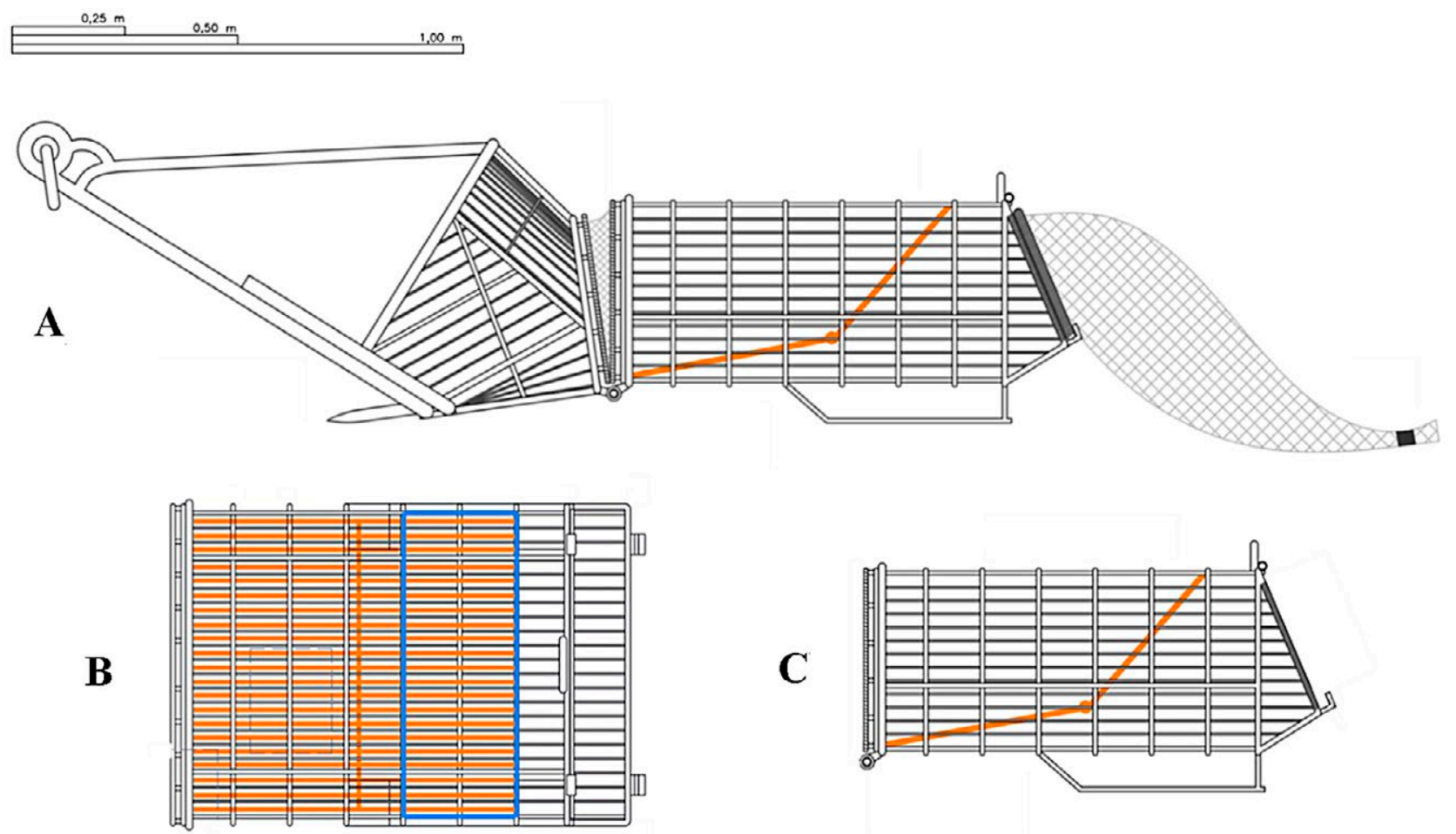

Fig. 6. - Schematic illustration of the proposal of technical modifications for the metallic grid dredge, including a bycatch reduction device (BRD) and a net bag: A, full size view; B, top view of the retention grid; C, lateral view of the retention grid.

(e.g. Brewer et al. 1998, Fonseca et al. 2005), little information of this type is available for bivalve fisheries, since most studies have focused on prawn and shrimp trawl fisheries. In the present case, the grid dredge should include, in the middle of the collecting system, an oblique metallic grid ending at an escape exit at the top of the cage (Fig. 6). By installing this BRD, it is expected that individuals larger than the openings will be guided upwards to the escape exit, while smaller individuals will pass through the openings of the BRD. Since the selection of the individuals that pass through the BRD will occur inside the grid cage, the spacing between the bars must be large enough to enable target individuals to pass through and thus avoid negative affects on the fishing yield. This type of BRD (i.e. a simple metallic grid that mechanically excludes unwanted catches according to their size) has been extensively reported as efficient for allowing bycatch to escape while maintaining the target catch. For instance, a significant decrease in the proportion of bycatch fish in trawl fisheries targeting the ocean shrimp (Pandalus jordani) was recorded following the implementation of a rigid-grid BRD (Hannah and Jones 2007). Likewise, significant bycatch reductions were achieved thanks to the use of the Nordmøre grid in the Brazilian artisanal shrimp fishery, with an extremely high decrease $(97 \%)$ in the weight of the abundant brachyurids present in the catches (Silva et al. 2012).

The survival of escaped organisms should also be considered, since the adoption of BRDs assumes that excluded individuals suffer negligible mortality (Crowder and Murawski 1998). Considering that previous underwater observations by Gaspar et al.
(2001) revealed that undamaged individuals that pass through the parallel rods of the metallic grid dredge rebury immediately or recover activity, the likelihood of survival of the escaped individuals is presumably high. Therefore, this BRD is expected to reduce both direct and indirect mortality, since it will allow the immediate escape of larger individuals from the fishing gear during the tow. They will be subject to less stress, recover their activity faster and be less exposed to predation. However, the modification proposed might also decrease the fishing yield, since during hauling there is a high likelihood of losing the target catch through the opening at the top of the dredge. To overcome this problem, an additional modification is required in the fishing gear: removing the rear part of the grid cage and attaching a net bag to the rear of the dredge in order to retain the catches during hauling (Fig. 6).

Gear-based solutions for reducing bycatch require an optimal combination of characteristics that decreases the amount of bycatch while maintaining or increasing the catches of target species. The likelihood of fishermen accepting a new or modified fishing gear can be expected to be low if the fishing yield decreases in comparison with the previous design of the fishing gear. For instance, the decreasing fishing yield following the adoption of the Nordmøre grid in the crustacean trawl fishery in Portugal raised concerns about whether fishermen would accept this gear modification (Fonseca et al. 2005). The overall results gathered in the present study recommend technical modifications to the current technical design of bivalve dredges, in order to adopt a BRD and include a retention net bag. For this reason, further experimental fishing surveys 
(performed throughout the year, using dredges with and without BRD towed simultaneously and side by side) are required to compare the fishing yield and profitability, catch composition, proportion of bycatch and discards, damage and mortality rates.

\section{ACKNOWLEDGEMENTS}

The authors would like to thank the colleagues André Carvalho, Rúben Lechuga, David Piló and Daniela Rosa (IPMA - Centre of Olhão) and Margarete Matias, Cláudia Roque and João Teixeira (IPMA - Molluscan Aquaculture Experimental Station of Tavira) for their helpful assistance in the biological sampling and survival experiments, respectively. The technical design of the fishing gear was kindly provided by Miguel Carneiro (IPMA - Headquarters in Lisbon). This study was performed within the framework of the research project "Science Technology and Society Initiative to Minimize Unwanted Catches in European Fisheries (MINOUW)" funded by the Research and Innovation Action (RIA) of the EU Horizon 2020 programme. This study received national funds through the Foundation for Science and Technology - FCT (project UID/ Multi/04326/2013). Paulo Vasconcelos was funded by a post-doctoral grant awarded by FCT (SFRH/ BPD/26348/2006). Thanks are also due to Dr Montserrat Demestre (Scientific Editor of Scientia Marina) and two anonymous reviewers for providing helpful suggestions to improve the manuscript.

\section{REFERENCES}

Alverson D.L., Freeberg M.H., Murawski S.A., et al. 1996. A global assessment of fisheries bycatch and discards. FAO Fish. Tech. Pap. 339: 1-233.

Alves F., Chícharo L., Nogueira A., et al. 2003. Changes in benthic community structure due to clam dredging on the Algarve coast and the importance of seasonal analysis. J. Mar. Biol. Assoc. U.K. 83: 719-729.

https://doi.org/10.1017/S0025315403007707h

Barros P., Sobral P., Range P., et al. 2013. Effects of sea-water acidification on fertilization and larval development of the oyster Crassostrea gigas. J. Exp. Mar. Biol. Ecol. 440: 200-206. https://doi.org/10.1016/j.jembe.2012.12.014

Bergmann M., Moore P.G. 2001. Mortality of Asterias rubens and Ophiura ophiura discarded in the Nephrops fishery of the Clyde Sea area, Scotland. ICES J. Mar. Sci. 58: 531-542. https://doi.org/10.1006/jmsc.2001.1046

Bergmann M., Taylor A.C., Moore P.G. 2001. Physiological stress in decapod crustaceans (Munida rugosa and Liocarcinus depurator) discarded in the Clyde Nephrops fishery. J. Exp. Mar. Biol. Ecol. 259: 215-229. https://doi.org/10.1016/S0022-0981(01)00231-3

Bianchi G., Gislason H., Graham K., et al. 2000. Impact of fishing on size composition and diversity of demersal fish communities. ICES J. Mar. Sci. 57: 558-571. https://doi.org/10.1006/jmsc.2000.0727

Birkett L. 1959. Production in benthic populations. ICES: NearNorthern Seas Committee, 42: 1-12.

Brewer D., Rawlinson N., Eayrs S., et al. 1998. An assessment of bycatch reduction devices in a tropical Australian prawn trawl fishery. Fish. Res. 36: 195-215. https://doi.org/10.1016/S0165-7836(98)00096-4

Broadhurst M.K., Kennelly S.J., Gray C. 2007. Strategies for improving the selectivity of fishing gears. In: Kennelly S.J. (ed.), By-catch Reduction in the World's Fisheries. Springer, Dordrecht Netherlands, pp. 1-21. https://doi.org/10.1007/978-1-4020-6078-6_1

Caddy J.F. 1973. Underwater observations on tracks of dredges and trawls and some effects of dredging on a scallop ground. J. Fish. Res. Board Can. 30: 173-180. https://doi.org/10.1139/f73-032

Catchpole T.L., Frid C.L.J., Gray T.S. 2005. Discards in North Sea fisheries: causes, consequences and solutions. Mar. Pol. 29: 421-430. https://doi.org/10.1016/j.marpol.2004.07.001

Chícharo L., Chícharo A., Gaspar M., et al. 2002a. Ecological characterization of dredged and non-dredged bivalve fishing areas off south Portugal. J. Mar. Biol. Assoc. U.K. 82: 41-50.

Chícharo L., Chícharo M., Gaspar M., et al. 2002b. Reburial time and indirect mortality of Spisula solida clams caused by dredging. Fish. Res. 59: 247-257. https://doi.org/10.1016/S0165-7836(02)00012-7

Clark W.G., Hare S.R. 1998. Accounting for bycatch in management of the Pacific halibut fishery. N. Am. J. Fish. Manag. 18: 809-821.

https://doi.org/10.1577/1548-8675(1998)018<0809:AFBIMO> 2.0.CO;2

Clarke K.R., Gorley R.N. 2006. PRIMER v6: User Manual/Tutorial. Primer-E Ltd, Plymouth, 190 pp.

Clarke K.R., Warwick R.M. 2001. Change in Marine Communities: An Approach to Statistical Analysis and Interpretation, 2nd ed. PRIMER-E Ltd, Plymouth, 175 pp.

Crowder L.B., Murawski S.A. 1998. Fisheries bycatch: implications for management. Fisheries 23: 8-17. https://doi.org/10.1577/1548-8446(1998)023<0008:FBIFM>2. $0 . \mathrm{CO} ; 2$

Direção Geral de Recursos Naturais (DGRM). 2015. Fisheries databases. Segurança e Serviços Marítimos. Lisboa, Portugal.

Dolbeth M., Viegas I., Martinho F., et al. 2006. Population structure and species dynamics of Spisula solida, Diogenes pugilator and Branchiostoma lanceolatum along a temporal-spatial gradient in the south coast of Portugal. Estuar. Coast. Shelf Sci. 66: $168-176$. https://doi.org/10.1016/j.ecss.2005.08.006

European Comission (EC). 2014. Facts and Figures on the Common Fisheries Policy, 2014 Edition. European Union, 44 pp.

FAO 2003. The ecosystem approach to fisheries. FAO Technical guidelines for responsible fisheries: 4, Rome, FAO Fish. Tech. Pap. 112 pp.

Fonseca P., Campos A., Larsen R.B., et al. 2005. Using a modified Nordmøre grid for by-catch reduction in the Portuguese crustacean-trawl fishery. Fish. Res. 71: 223-239. https://doi.org/10.1016/j.fishres.2004.08.018

Gaspar M.B. 1996. Bivalves do litoral oceânico algarvio. Aspectos da biologia, ecologia e das pescarias dos mananciais de interesse económico: aplicação à gestão dos recursos. $\mathrm{Ph}$. D. thesis, Universidade do Algarve, Faro, 282 pp.

Gaspar M.B., Chícharo L.M. 2007. Modifying dredges to reduce by-catch and impacts on the benthos. In: Kennely S.J. (ed.), Bycatch Reduction in the World's Fisheries. Springer, Dordrecht Netherlands, pp. 95-140. https://doi.org/10.1007/978-1-4020-6078-6_5

Gaspar M.B., Monteiro C.C. 1999. Indirect mortality caused to juveniles of Spisula solida due to deck exposure. J. Mar. Biol. Assoc. U.K. 79: 567-568. https://doi.org/10.1017/S0025315498000708

Gaspar M.B., Castro M., Monteiro C.C. 1998. Influence of tow duration and tooth length on the number of damaged razor clams Ensis siliqua. Mar. Ecol. Prog. Ser. 169: 303-305. https://doi.org/10.3354/meps169303

Gaspar M.B., Castro M., Monteiro C.C. 1999. Effect of tooth spacing and mesh size on the catch of the Portuguese clam and razor clam dredge. ICES J. Mar. Sci. 56: 103-110. https://doi.org/10.1006/jmsc.1998.0423

Gaspar M.B., Dias M.D., Campos A., et al. 2001. The influence of dredge design on the catch of Callista chione (L. 1758). Hydrobiologia 465: 153-167. https://doi.org/10.1023/A:1014587212528

Gaspar M.B., Leitão F., Santos M.N, et al. 2002a. Influence of mesh size and tooth spacing on the proportion of damaged organisms in the catches of the Portuguese clam dredge fishery. ICES J. Mar. Sci. 51: 1228-1236. https://doi.org/10.1006/jmsc.2002.1310

Gaspar M.B., Chícharo L.M., Vasconcelos P., et al. 2002b. Depth segregation phenomenon in Donax trunculus (Bivalvia: Donacidae) populations of the Algarve coast (southern Portugal). Sci. Mar. 66: 111-121

https://doi.org/10.3989/scimar.2002.66n2111 
Gaspar M.B., Leitão F., Santos M.N., et al. 2003a. A comparison of direct macrofaunal mortality using three types of Portuguese clam dredge. ICES J. Mar. Sci. 60: 733-742. https://doi.org/10.1016/S1054-3139(03)00023-7

Gaspar M.B., Santos M.N., Leitão F., et al. 2003b. Recovery of substrates and macro-benthos after fishing trials with a new Portuguese clam dredge. J. Mar. Biol. Assoc. U.K. 83: 713-717. https://doi.org/10.1017/S0025315403007690h

Gaspar M.B., Moura P., Pereira F., et al. 2015. Ponto de situação dos bancos de bivalves na Zona Sul. Relatório de Campanha de Pesca do IPMA, $21 \mathrm{pp}$.

Gruffydd L.D. 1972. Mortality of scallops on a Manx scallop bed due to fishing. J. Mar. Biol. Assoc. U.K. 52: 449-455. https://doi.org/10.1017/S0025315400018816

Guyader O., Berthou P., Koutsikopoulos C., et al. 2013. Small scale fisheries in Europe: A comparative analysis based on a selection of case studies. Fish. Res. 140: 1-13. https://doi.org/10.1016/j.fishres.2012.11.008

Hall M.A., Alverson D.L., Metuzals K.I. 2000. By-catch: problems and solutions. Mar. Pollut. Bull. 41: 204-219. https://doi.org/10.1016/S0025-326X(00)00111-9

Hannah R.W., Jones S.A. 2007. Effectiveness of bycatch reduction devices (BRDs) in the ocean shrimp (Pandalus jordani) trawl fishery. Fish. Res. 85: 217-225. https://doi.org/10.1016/j.fishres.2006.12.010

Hauton C., Atkinson R.J.A., Moore P.G. 2003. The impact of hydraulic blade dredging on a benthic megafaunal community in the Clyde Sea area, Scotland. J. Sea Res. 50: 45-56. https://doi.org/10.1016/S1385-1101(03)00045-5

Hill A.S., Brand A.R., Wilson U.A.W., et al. 1996. Information of by-catch composition and the numbers of by-catch animals killed annually on Manx scallop fishing grounds. In: Greenstreet S.P.R., Tasker M.L. (eds), Aquatic Predators and their Prey. Blackwell Science, Oxford, pp. 111-115.

ICES. 2014. Report of the Workshop on Methods for Estimating Discard Survival (WKMEDS), 17-21 February 2014, Copenhagen, Denmark. ICES CM 2014/ACOM:51, 114 pp.

Jenkins S.R., Beukers-Stewart B.D., Brand A.R. 2001. Impact of scallop dredging on benthic megafauna: a comparison of damage levels in captured and non-captured organisms. Mar. Ecol. Prog. Ser. 215: 297-301. https://doi.org/10.3354/meps215297

Jennings S., Kaiser M.J. 1998. The effect of fishing on marine ecosystems. Adv. Mar. Biol. 34: 201-252. https://doi.org/10.1016/S0065-2881(08)60212-6

Kaiser M.J., Spencer B.E. 1995. Survival of by-catch from a beam trawl. Mar. Ecol. Prog. Ser. 126: 31-38. https://doi.org/10.3354/meps 126031

Kelleher K. 2005. Discards in the world's marine fisheries: an update. FAO Fish. Tech. Pap. 470: 1-131 pp. http://www.fao.org/docrep/008/y5936e/y5936e00.htm

Leitão F., Baptista V. 2017. The discard ban policy, economic trends and opportunities for the Portuguese fisheries sector. Mar. Pol. 75: 75-83. https://doi.org/10.1016/j.marpol.2016.10.012

Leitão F., Gaspar M.B., Santos M.N., et al. 2009. A comparison of bycatch and discard mortality in three types of dredge used in the Portuguese Spisula solida (solid surf clam) fishery. Aquat. Living Resour. 22: 1-10. https://doi.org/10.1051/alr/2009001

Leitão F., Range P., Gaspar M.B. 2014. Survival estimates of bycatch individuals discarded from bivalve dredges. Braz. J. Oceanogr. 62: 257-263. https://doi.org/10.1590/s1679-87592014067006204

McCaughran D.A. 1992. Standardized nomenclature and methods of defining bycatch levels and implications. In: Schoning R.W., Jacobson R.W., Alverson D.L., et al. (eds), Proceedings of the National Industry Bycatch Workshop, 4-6 February 1992, Newport, Oregon, pp. 200-201.

Medcof J.C., MacPhail J.S. 1964. A new hydraulic rake for softshell clams. Proc. Natl. Shellfish. Ass. 53: 11-31.
Morfin M., Méhault S., Benoît H.P., et al. 2017. Narrowing down the number of species requiring detailed study as candidates for the EU Common Fisheries Policy discard ban. Mar. Pol. 77: 23-29. https://doi.org/10.1016/j.marpol.2016.12.003

Oliveira M.C.C. 2014. Application of Bio-Economic Models in the Management of the Dredge Fleet in Portugal. Ph. D. thesis, Faculdade de Engenharia da Universidade do Porto, $145 \mathrm{pp}$.

Oliveira M.C.C., Gaspar M.B., Paixão J.M.P. 2007. Medição e Análise da Produtividade da Frota da Ganchorra na Costa Algarvia. In: del Hoyo J., Pereira J. (eds), Observatorio científico de las pesquerías artesanales - SocioEconomía, Universidad de Huelva, pp. 267-289.

Palma J., Reis C., Andrade J.P. 2003. Flatfish discarding practices in bivalve dredge fishing off the south coast of Portugal (Algarve). J. Sea Res. 50: 129-137. https://doi.org/10.1016/S1385-1101(03)00065-0

Pauly D., Christensen V., Dalsgaard J., et al. 1998. Fishing down marine food webs. Science 279: 860-863. https://doi.org/10.1126/science.279.5352.860

Pauly D., Christensen V., Guénette S., et al. 2002. Towards sustainability in world fisheries. Nature 418: 689-695. https://doi.org/10.1038/nature01017

Pranovi F., Raicevich S., Franceschini G., et al. 2001. Discard analysis and damage to non-target species in the "rapido" trawl fishery. Mar. Biol. 139: 863-875. https://doi.org/10.1007/s002270100646

Ramsay K., Kaiser M.J., Hughes R.N. 1998. Responses of benthic scavengers to fishing disturbance by towed gears in different habitats. J. Exp. Mar. Biol. Ecol. 224: 73-89. https://doi.org/10.1016/S0022-0981(97)00170-6

Robinson R.F., Richardson C.A. 1998. The direct and indirect effects of suction dredging on a razor clam (Ensis arcuatus) population. ICES J. Mar. Sci. 55: 970-977. https://doi.org/10.1006/jmsc. 1998.0356

Silva C.N., Broadhurst M.K. Dias J.H et al. 2012. The effects of Nordmøre-grid bar spacings on catches in a Brazilian artisanal shrimp fishery. Fish. Res. 127: 188-193. https://doi.org/10.1016/j.fishres.2012.01.004

Szostek C.L., Murray L.G., Bell E., et al. 2017. Regional variation in bycatches associated with king scallop (Pecten maximus L.) dredge fisheries. Mar. Environ. Res. 123: 1-13. https://doi.org/10.1016/j.marenvres.2016.11.006

Thrush S.F., Dayton P.K. 2002. Disturbance to marine benthic habitats by trawling and dredging - implications for marine biodiversity. Annu. Rev. Ecol. Syst. 33: 449-473. https://doi.org/10.1146/annurev.ecolsys.33.010802.150515

Tirado C., Rueda J.L., Salas C. 2011. Reproduction of Donax trunculus in the littoral of Huelva (southern Atlantic Spain): is there any difference with the Mediterranean population from the Andalusian coast? Iberus 29: 47-57.

Trewin N.H., Welsh W. 1972. Transport, breakage and sorting of the bivalve Mactra corallina on Aberdeen beach, Scotland. Paleogeogr. Paleoclimatol. Paleoecol. 12: 193-204. https://doi.org/10.1016/0031-0182(72)90059-4

Urra J., García T., Gallardo-Roldán H., et al. 2017. Discard analysis and damage assessment in the wedge clam mechanized dredging fisheries of the northern Alboran Sea (W Mediterranean Sea). Fish. Res. 187: 58-67. https://doi.org/10.1016/j.fishres.2016.10.018

Vasconcelos P., Morgado-André A., Morgado-André C., et al. 2011. Shell strength and fishing damage to the smooth clam (Callista chione): simulating impacts caused by bivalve dredging. ICES J. Mar. Sci. 68: 32-42. https://doi.org/10.1093/icesjms/fsq149

Vogel C., Kopp D., Méhault S. 2017. From discard ban to exemption: How can gear technology help reduce catches of undersized Nephrops and hake in the Bay of Biscay trawling fleet? J. Environ. Manage. 186: 96-107. https://doi.org/10.1016/j.jenvman.2016.10.017 